\title{
New Perspectives on Innovative Drug Discovery: An Overview
}

\author{
Si-Yuan Pan ${ }^{1 *}$, Shan Pan $^{2 *}$, Zhi-Ling Yu ${ }^{2}$, Dik-Lung Ma ${ }^{2}$, Si-Bao Chen ${ }^{3}$, Wang-Fun Fong ${ }^{2}$, Yi-Fan Han ${ }^{4}$, Kam-Ming \\ $\mathrm{Ko}^{5}$ \\ ${ }^{1}$ Beijing University of Chinese Medicine, China; ${ }^{2}$ Hong Kong Baptist University, China; ${ }^{3}$ Chinese Academy of Medical \\ Science \& Peking Union Medical College, China; ${ }^{4}$ Hong Kong Polytechnic University, China; ${ }^{5}$ Hong Kong University \\ of Science \& Technology, China.
}

Received, September 1, 2010; Revised, September 22, 2010; Accepted, October 28, 2010; October 29, 2010.

\begin{abstract}
Despite advances in technology, drug discovery is still a lengthy, expensive, difficult, and inefficient process, with a low rate of success. Today, advances in biomedical science have brought about great strides in therapeutic interventions for a wide spectrum of diseases. The advent of biochemical techniques and cutting-edge bio/chemical technologies has made available a plethora of practical approaches to drug screening and design. In 2010, the total sales of the global pharmaceutical market will reach 600 billion US dollars and expand to over 975 billion dollars by 2013. The aim of this review is to summarize available information on contemporary approaches and strategies in the discovery of novel therapeutic agents, especially from the complementary and alternative medicines, including natural products and traditional remedies such as Chinese herbal medicine.
\end{abstract}

\section{INTRODUCTION}

Over the past decades, despite the prolongation of the average human lifespan resulting from the great strides in medical sciences, a variety of diseases that affect our wellbeing and whose treatment remains problematic continue to emerge. Jean-Jacques Rousseau $(1712 \sim 1778)$ stated: "The history of civilization is also one of human diseases". Conceivably, the emergence of human diseases will proceed at a pace comparable to the advances in experimental and clinical sciences. As such, scientists all over the world have been searching for novel drugs that might be used for the prevention and treatment of life-threatening and/or debilitating diseases, as well as for the improvement of wellbeing and quality of life in the aging population $(1,2)$. As a result, 554 drug candidates, including 504 small molecules, 40 recombinant proteins and 10 monoclonal antibodies, were approved in USA between 1980 to 2001 (3). Since 1950, approximately 1,200 new therapeutic agents have been approved by Food and Drug Administration (FDA) (4). The amount of industrial investment on drug discovery has surpassed those on electronics, computer, aerospace and aviation $(5,6)$. It has been estimated that it may cost more than 800 million US dollars and require 10 to 17 years to develop a new drug (7). However, the fast-track program of FDA, set up in 1997, has expedited drug approvals for agents that fight serious or life-threatening conditions such as cancer, HIV/AIDS as well as rare and orphan diseases (8). Orphan drug programs have been also established in EU, Japan and Australia to encourage the development of medicines to treat rare diseases (9).

Despite the steady increase in the total amount of money spent on pharmaceutical research and development (R\&D) over the past decade, the number of new drug approvals has declined in recent years. In 2008, only 31 new therapeutic agents including both chemicals and biologics for therapeutic use as well as new diagnostic agents, have reached the market (10). This outcome is not satisfactory in the high-tech era of the $21^{\text {st }}$ century. Previously, we have commented on the current R\&D of Chinese herbal medicine (CHM, or Zhong-Yao) in China (11). Here, we provide a brief account on current trends in innovative drug discovery, which together with the previous companion review, should provide a panorama of modern drug discovery, including chemical drug and natural or traditional remedy $\mathrm{R} \& \mathrm{D}$. The present review focuses on the concepts of innovative drug discovery rather than on specific pharmaceutical techniques and knowledge.

Corresponding Author: Si-Yuan Pan, Beijing University of Chinese Medicine, Beijing 100102, China. E-mail: siyuan-pan@163.com 
Pharmaceutical development depends on breakthroughs in technologies and concepts. In our view, the latter is more important than the former. We can acquire pharmaceutical techniques and methods by various means, but creative ideas play a pivotal role in innovative drug development.

\section{THE PRESENT AND FUTURE OF DRUG DISCOVERY}

Over the past decades, most drugs have been discovered either by identifying active ingredients from natural products or traditional remedies, or by chemical synthesis. Approaches to modern drug discovery can be summarized as follows.

\section{Recombinant proteins}

In the $20^{\text {th }}$ century, the completion of the Human Genome Project, which is the most influential accomplishment in biomedical sciences, has had a strong impact on basic research in biological sciences, such as structural biology, nucleic acid chemistry, protein chemistry, carbohydrate chemistry, and more importantly, on drug discovery $(12,13)$. The discovery of functional genes coded for proto-proteins and the subsequent unraveling of their functional interactions with signaling molecules likely offer new strategies for new drug discovery. The advent of recombinant DNA technology has made possible the development of a new generation of therapeutics. Such an approach is exemplified by the use of the $\mathrm{G}$ protein-coupled receptor family as a major target for drug discovery (14). Drug candidates incorporating the pharmacophore have been explored with the aim of producing optimal compounds of lower molecular weight (15).

Drugs derived from recombinant proteins include well-known products such as human insulin, haemophiliac globulins, growth hormone, and erythropoietin, all of which are referred to as 'first generation' recombinant products. At the present time, there are approximately 20 antibody products and almost 150 approved protein-based products that are commercially available in the United States alone (16). Biopharmaceuticals, which are macromolecular drugs developed from biotechnological research, are considered newcomers in drug R\&D. Over 130 products are currently marketed, including 23 "blockbusters", and the value of biopharmaceutical market was 48 billion US dollars in 2007 (17). The market value of biopharmaceuticals will exceed $\$ 100$ billion in 2010 and $\$ 400$ billion by 2030 (18). Among the leading biopharmaceutical products (with a total sales of $\$ 38$ billion) are erythropoietin, insulin, and monoclonal antibodies.

Monoclonal antibodies comprise the majority of protein drug candidates currently under clinical development because of their versatility in therapeutic applications. A total of 21 products have been approved in the USA, with additional products being marketed outside the country, and over 200 monoclonal antibody candidates are currently under clinical investigation (19). Biopharmaceuticals, driven by large profit margins, is likely to be the mainstream of pharmaceutical R\&D in the coming years. For example, avastin, which is manufactured by Genentech and clinically prescribed for the treatment of lymphoma and carcinoma of mammary glands, showed a $41 \%$ increase in sales within 3 months, with sales revenue amounting to 1.1 billion US dollars (20). The sophistication of genetic engineering and bioprocess technology has made possible the mass production of biopharmaceuticals such as insulin and human growth hormone. In 1987, the FDA approved the first genetically engineered hepatitis B vaccine for human use. Since then, genetic engineering and bioprocess technology has been adopted in the manufacture of a number of biopharmaceuticals and vaccines. In addition to biopharmaceutical development, recombinant DNA (rDNA) technology has been applied to diagnose such devastating diseases as cancer (21), Alzheimer's disease (22), diabetes (23) and cystic fibrosis (24), and to develop therapies to address these conditions whose clinical management remains problematic and challenging.

Development of genetically-modified (GM) foods is another area where rDNA has important applications. GM foods such as soybean, corn, canola, and cotton seed oil, with desirable traits, such as increased resistance to herbicides or improved nutritional content, have been put on the market since the early 1990s (25). Future applications of GM foods can be therapeutically-related - for example, GM bananas that produce human vaccines against infectious diseases such as hepatitis B (26). While the practicality or feasibility of commercial production has yet to be fully tested, the next decade may see an exponential increase in drug-related GM products.

\section{Nucleic acids with specific base sequences}

Nowadays, we have gained insights into the genetic make-up of a host of living organisms (bacteria, plants, animals, and humans), and have identified specific genes and their products (protein, enzymes, and receptors, etc.) with regard to their role in health and disease. Biochemical 
processes involved in the functioning of an organism are regulated by the information stored in DNA. As such, hereditary traits of a cell, organism, or population may be altered by the manipulation of genetic material. Using molecular cloning and transformation techniques, the structure and characteristics of genes can be altered in such a way that insulin can be produced in bacteria by a human insulin gene and erythropoietin in hamster ovary cells or other biological systems (27-29).

Another exciting possible application of genetic engineering is the use of gene therapy for the treatment of genetic disorders, in which epigenome-derived drugs have a strong potential in providing highly selective treatments (30). At the present time, two adenoviral gene therapy products have been approved for clinical use in China, and at least four products are in phase III clinical trials elsewhere (31). Gene therapy involves the transfer of genetic material (nucleic acids with a specific sequence) into the cells of an individual in the hope of achieving a therapeutic benefit. This involves the specific modification of genetic information in the body, with the aim of preventing or curing a disease. Genetic modifications may rectify a genetic defect that will otherwise lead to the synthesis of a defective protein, or supplement genetic information to modify cellular characteristics. In 1990, the first clinical trial involving gene therapy was conducted in patients suffering from adenosine deaminase deficiency, a genetic condition characterized by immunodeficiency (32). Although the technique of gene therapy is still very much in its infancy, it offers possible cures for diseases that are not manageable by conventional therapeutic intervention. Currently, gene therapy is mainly focused on the treatment of cancers, and preclinical studies on various diseases, genetic immunization protocols and improvement of vector design are under way.

Although gene therapy usually aims to replace a defective protein in order to restore normal function, the treatment of autoimmune diseases involves the delivery of proteins through ex vivo or in vivo gene transfer (33). Gene therapy may be effective in the treatment of monogenic disorders but not in the treatment of polygenic diseases characterized by multiple defects such as diabetes mellitus type 2, schizophrenia and multiple sclerosis. In addition, the integration of recombinant vector systems may adversely alter the genetic arrangement of the target cell, causing a condition called "insertional mutagenesis" which resulted in leukemia in five patients who participated in clinical trials for the treatment of severe combined immunodeficiency-X1, and one of these patients died (34). Therefore, the feasibility of gene therapy must be carefully evaluated and, in particular, the selection of patients is crucial for successful treatment. More often than not, a therapeutic intervention may also not be suitable for all patients because of individual variations in physiological and pathological states. The effective application of gene therapies and recombinant protein products largely depends on the development of individualized medicine, particularly in the area of cancer chemotherapy $(35,36)$.

\section{Plant-derived compounds}

It has been estimated that approximately 420,000 plant species exist in nature. Plants provide humans with oxygen, food and medicine as well as other necessities of life. Plants not only constitute the major part of human foodstuffs, but they also have formed the basis of therapeutic interventions in traditional medicine systems throughout human history. Even with modern technology, plants are still used as a source of medicines and continue to serve as the basis for many pharmaceutical or cosmetic products. Many therapeutic agents used today are related to plants. While products derived from Ginkgo biloba are top-selling phytopharmaceuticals in Europe and a popular dietary supplement in USA $(37,38)$, the anticancer agent paclitaxel (Taxol) and the antimalarial agent artemisinin are extracted from the Yew tree and Artemisia annua, respectively $(39,40)$.

During the past 100 years, the development of drugs for treating human diseases has been mainly based on a variety of compounds derived from plants. Well known examples include aspirin, morphine, reserpine, digitalis and quinine. At the present time, approximately 50,000 metabolites have been identified in plants, and it is predicted that the final number will exceed 200,000 (41). A huge number of naturally-occurring compounds are available for further exploitation of their potential use as therapeutic agents in medicine. This was recently highlighted in the discovery of two additional inhibitors of TNF- $\alpha$ using high throughput virtual ligand screening, a protein linked to a number of autoimmune and inflammatory diseases (42). The identified natural products showed improved potency compared to the only commercial available TNF- $\alpha$ inhibitor described in the literature (43). This highlights the potential of natural products in their natural form and as templates for synthetic modification as treatment for a number of diseases. One plant species often contains 1000 unique chemical 
entities and this provides chemists with chemical structures which cannot be synthesized in the laboratory or on an industrial scale in a feasible way. Plants provide us with a large collection of rich, complex and highly varied structures. Unfortunately, many plant species are extinct due to adverse environmental changes, and the extinction rate has been accelerating.

The launch of a new generation of botanical therapeutics, including plant-derived pharmaceuticals, multi-component botanical drugs, functional foods and plant-produced recombinant proteins, results from a better understanding of the relationship between plant and human health. Many of these products will soon complement conventional pharmaceuticals in the treatment, prevention and diagnosis of diseases. Plants of particular interest are those containing polyphenols, tannins and flavonoids, which possesses antioxidant and other pharmacological properties $(44,45)$, particular in cancer chemotherapy as P-glycoprotein inhibitor (46). In this regard, there are 6 kinds of antioxidants from plants or CHM being used in China, including butylated hydroxyanisole, dibutylhydroxytoluene, n-propyl gallate, tea polyphenols, licorice root antioxidant, and rosemary acid.

In addition, there are a large number of active compounds derived from phytochemicals and their metabolites. For example, N-hydroxy-N'-(3,4,5-trimethoxphenyl)-

3,4,5-trimethoxy-benzamidine, a new resveratrol derivative, has shown considerable antitumor activity against human pancreatic cancer cells and it could prove to be a promising candidate for further investigations to establish a new chemotherapeutic regimen (47). Resveratrol also possesses antioxidant, anti-inflammatory, and neuroprotective activities (48), as well as the ability to protect against methotrexate-induced hepatic injury (49). 2-Allylphenol, a registered fungicide in China for controlling fungal diseases on tomato, strawberry and apple, is a synthetic congener with structural resemblance to ginkgo, an active ingredient isolated from Ginkgo biloba (50).

In addition to single chemical entities developed from plants, herbal medicine with multi-ingredients has been successfully developed from plants. Being more efficacious than a single active ingredient or a single herb, the development of multi-ingredient herbal medicine may represent a new direction for modern drug $R \& D$, especially those from natural or traditional remedies. It seems likely that the complexity of human body function will necessitate a multi-target approach in treating diseases. This is exemplified by a successful application of "cocktail" therapy in patients with AIDS (51) and the multi-drug approach in patients with hypertension (52).

A good example of phytomedicine is the commercial preparation of Ginkgo leaf extract (eg. EGb 761), which is a very complex mixture prepared from raw leaves by a series of extraction and purification steps. The Ginkgo extract is comprised of 2 main bioactive constituents, flavonoid glycosides (24\%) and terpene lactones $(6 \%)$, along with less than $5 \mathrm{ppm}$ of an allergenic component, ginkgolic acid (53). Given the large number of monomeric compounds present in the Ginkgo extract, it is not surprising that it can produce a multifaceted therapeutic benefit in terms of neuroprotection, anticancer, cardioprotection, stress relief, and memory enhancement, as well as improvements in tinnitus, geriatric complaints, and psychiatric disorders (53).

\section{CHM-derived compounds}

A wide array of pharmacologically active compounds, which were isolated from CHM with proven clinical efficacy, would be a gold mine for drug discovery. In China, drugs developed from CHM are described more details in elsewhere (11).

In ancient times, the Chinese largely depended on local flora and fauna for their foodstuffs and medicines. They would experiment on various animals, plants, and minerals to find out what effects they could produce in humans. As a result, many crude materials (i.e. CHM) were found to have medicinal uses. China is covered by huge and stratified geographical regions which contain a variety of flora and fauna. As such, CHM possesses a huge collection of medicinal materials which have been documented systematically according to their function and used under the guidance of Chinese medicine theory. It has a long history of use in China and is generally regarded as safe. CHM therefore provides a wealth of potential source materials for drug discovery. The huge resource of CHM includes 11,146 kinds of medicinal plants, 1,581 kinds of medicinal animals, 80 kinds of mineral drugs, and more than 50 kinds of processed CHM, including more than 5,000 clinically validated folk medicines (54). By 2007, China had collected 3,563 extracts, 64,715 formulations, and 5,000 single compounds from 3,000 Chinese herbs (55). Pharmacological screening has revealed a large number of biologically active compounds which are available for structural 
optimization and in-depth pharmacological evaluation. At present, there are about 130 kinds of chemical drugs obtained from lead compounds or their derivatives from CHM.

Pi-Shuang (arsenic trioxide, arsenous oxide, arsenous acid anhydride in English; Arsenolite, Arsenopyrite, Realgar in Latin), an inorganic compound with the chemical formula $\mathrm{As}_{2} \mathrm{O}_{3}$, is a toxic CHM $(56,57)$, with an acute lethal dose being estimated to be 70 to $200 \mathrm{mg} / \mathrm{kg} /$ day in adults (58). Since ancient times, Pi-Shuang has been used either as a poison for suicide and murder or as a therapeutic agent for treating disorders such as carbuncle, scrofula, malaria, hemorrhoids, ulcer, dysentery, noma, asthma, and ringworm. This application of Pi-Shuang is the so called "use poison against poison" in Chinese medicine, which dates back to $200 \mathrm{BC}(59,60)$. Pi-Shuang is an impure mixture which contains a small amount of sulfur and sulfide. Since arsenic trioxide was first purified and used in controlled studies in China in the 1970s, it has been widely studied throughout the world (61). Currently arsenic trioxide is an effective therapy in acute promyelocytic leukemia (APL), resulting in the prolongation of disease free survival and a reduction in the time required for complete remission and in relapse rate of newly diagnosed APL patients (62-64). In addition, it also produced therapeutic effect on some solid tumors such as multiple myeloma $(65,66)$, lymphoma (67), and hepatic carcinoma, and other cancers $(68,69)$.

Huperzine A is a naturally occurring sesquiterpene alkaloid compound found in the plant firmoss Huperzia serrata, a CHM for treating bruises, snake bite, swelling, congestion diseases, and schizophrenia (70-72). This drug has been shown to be beneficial in treating Alzheimer's disease and vascular dementia as a result of acetylcholinesterase inhibition and/or other biochemical actions (73,74). Paclitaxel (taxol) with anti-cancer activities (75), berberin with multiple pharmacological activities (76), and artemisin with anti-malarial activity (77) were all discovered from CHM. Both bifendate (dimet-hyl-4,4'-dimethoxy-5,6,5'6'-dimethylene-di oxybipheny1-2,2'-dicarboxylate) and bicyclol (4,4'-dimethoxy-5,6,5',6'-dimethylene-dioxy-2-hy droxymethyl-2'-carbonyl biphenyl), which are clinically prescribed for patients with chronic hepatitis in China (78), are derived from schisandrin

(dimethyl-4,4'-dimethoxy-5,6,5',6-dimethylene dioxybiphenyl-2,2'-dicarboxylate) present in the fruit of Schisandra chinensis (Bei-Wu-Wei-Zi) $(79,80)$, a commonly used Chinese herb (81).
Recently, they have been shown to down-regulate hepatic lipid levels in hypercholesterolemic mice (82-85). Curcumin from CHM "Curcuma longa" showed promising therapeutic effects on inflammatory bowel disease and cancers, as well as on retarding the aging process (86-88).

\section{Microorganism-derived compounds}

With the discovery of penicillin and sulfanilamide in the mid 1930's followed by subsequent advances in antibiotic development, many scientists claimed that bacterial diseases were no longer of great clinical concern or research interest. However, microbes did not vanish from the planet just because science had invented anti-microbial agents and vaccines. Far from being defeated, killer microbes returned with a vengeance.

\section{Discovery}

The extension of modern life and the discovery of antibacterial drugs are inseparable. Antibiotic derived from bacteria is a major component of anti-infective drugs. Microorganisms, including bacteria, fungi, archaea, protists and viruses, were the first forms of life on earth. The number of prokaryotes on earth is estimated to be approximately $5 \times 10^{30}$, accounting for at least half the biomass on earth. These microbes are the simplest and yet the most diverse creatures on earth. It is believed that microorganisms have 3-4 billion years of evolutionary history, but the history of human evolution spans only 200 million years. Therefore, the ability of microbes to survive and adapt to the environment as well as to utilize competitive means and strategies for existence are more profound than one can imagine.

Wiping out the competitors with toxins is one of the survival means in microorganisms. Alternatively, microbes can protect themselves against harmful assault from rivals. In this regard, it might be possible to utilize these microbial properties for the benefit of human health through modern technology. Microorganisms have been invaluable for discovering drugs and lead compounds, especially in the development of anti-infection and anti-cancer agents. However, drug options for treatment of infections are increasingly limited. Since the late 1960's only two novel classes of antibiotics, namely, oxazolidinones and cyclic lipopeptides, have been launched in the market.

Microorganisms can be utilized for therapeutic purposes in the following ways: 1) extract or synthesize compounds of medicinal value from microbial cells or culture medium; 2) 
make microbial metabolites as lead compounds for the development of novel therapeutic agents with potential clinical applications in various fields of medicine; 3) reconstruct the bacterial DNA to produce therapeutic agents through genetic engineering; and 4) application of the intact microbes for specific treatment directly. Until the development of penicillin in the early 1940 s, most natural product-derived drugs were obtained from terrestrial plants. The success of penicillin derived from Penicillium in treating infection led to a rapid growth in the use of microorganisms for drug discovery. Soil and water samples were collected from all over the world in order to study new bacterial or fungal strains for exploring new antibacterial agents, such as the cephalosporins from Cephalosporium acremonium, tetracyclines from Streptomyces aureofaciens, aminoglycosides from the Streptomyces genus, rifamycins from Amycolatopsis mediterranei, and chloramphenicol from Streptomyces venezuelae. Terrestrial microorganisms are a plentiful source of structurally diverse bioactive substances, and they have made important contributions to the discovery of many anti-bacterial agents. Philosophically, everything in the world has two sides. The mass production and overuse of antibiotics, over the past few decades, has brought about an alarming increase in infections caused by antibiotic-resistant pathogens such as methicillin-resistant Staphylococcus aureus which is estimated to cause $\sim 19,000$ deaths per year in the USA $(89,90)$.

Metabolites from microorganisms have been developed into therapeutic agents for immunosuppressive, cholesterol-lowering, anti-helmintic, anti-diabetic, and anti-cancer actions (91). For instance, asperlicin, a mycotoxin derived from the fungus Aspergillus alliaceus, is a novel antagonist of cholecystokinin; lovastatin produced by certain higher fungi such as Pleurotus ostreatus (oyster mushroom) and closely related Pleurotus spp was the lead compound for a series of drugs (statins) used to lower cholesterol levels (92); cyclosporin produced by the fungus Beauveria nivea is used as immunosuppressant after organ transplantation (93). With the aforementioned successful examples, it is conceivable that microorganism-based drug discovery offers a great potential in drug development. Furthermore, particulate antigen delivery systems, such as microorganism-derived adjuvants, emulsions and polysaccharides, have been developed over the last 30 years (94).

Live and nonpathogenic microorganisms are usually administered to improve microbial balance, particularly in the gastrointestinal tract. The probiotics such as Saccharomyces boulardii yeast and lactic acid bacteria are regulated as dietary supplements and foods (95). For example, Lactobacillus casei is useful for lowering high cholesterol levels and reducing the risk of gastric cancer $(96,97)$. With the use of live microbes in humans (98), the understanding of the function of commensal (a form of symbiosis in which one microorganism derives benefit but another is unaffected) microbes in our body could greatly facilitate drug discovery from such organisms.

\section{Hypothesis}

The human body contains 20 times more microbes than it does cells. There are over 400 distinct species of microorganisms in various regions of the human digestive tract. Since these bacteria can affect the biological process in our gut, they can also inevitably influence the bioavailability and response to orally administered drugs and dietary compounds (99). Therefore, microbes should be considered in devising the strategy for novel drug development. New generation pharmacotherapy targeting the structure and functioning of the intestinal microbiota may well be a promising area for future development.

With the increasing incidence of incurable diseases such as cancer and AIDS, as well as the growing number of virulent microbes exhibiting antibiotic resistance, it is reasonable to speculate that virulent microbes will be threatening the health of millions of people worldwide. Based on the positive correlation between the increasing incidence of incurable diseases and the escalating number of strains of microorganisms discovered, one solution for the impending health threat is to look for effective anti-microbial agents. On the basis of the selective damage of HIV and hepatitis viruses on immune cells and hepatocytes, respectively, alteration in the phenotypic behavior of these viruses by genetic modification may offer a new hope in the treatment of leukemia and liver cancer, possibly by destroying liver cancer cells and blood cancer cells using altered hepatitis virus or HIV, respectively.

Insects are often described as superorganisms, and many functional parallels between organisms and superorganisms can be drawn. Indeed, human skin and the gastrointestinal and respiratory tracts are colonized by a complex microbial ecosystem (100-102). The number of bacteria colonizing skin and mucosal surfaces exceeds by 10 -fold the number of cells constituting the human body. In 
particular, human gut is home to a vast consortium of symbiotic bacteria. Therefore, it has been proposed that humans themselves are complex biological "superorganisms". Under normal conditions, these microbes not only maintain health through microbe-microbe interactions, but also promote a harmony among microbes. Recent findings have shown that the gastrointestinal microbiota affects insulin resistance, inflammation, and adiposity via interactions with epithelial and endocrine cells (103). Evidence has been obtained supporting the role of altered commensal gut flora in human disease (104). Additionally, it has become common knowledge that the bacteria living in the human digestive system also contribute to gut immunity, synthesize vitamins and ferment complex indigestible carbohydrate (105).

It is clear that various types of microorganisms possess a variety of characteristics. For example, bacterioviruses are viruses that can destroy (kill) the corresponding bacteria, but are harmless to human's cells (106). In this respect, scientists may find or produce new microorganisms with specific properties through genetic engineering for curing human diseases. Possibly, fat-utilizing bacteria might prove effective for removing atheromatous plaques on the arterial walls and consuming excess lipids in the blood and/or fat cells. Thrombus-dissolving bacteria might be developed for dredging blood vessels that are blocked by clots, and tumor-destroying bacteria for killing cancer cells. These assumptions are based on the success of man-made bacteria (29) and the prevention of hepatic encephalopathy by targeting enteric bacterial flora (107).

\section{Marine-derived compounds}

In the past, most drugs were discovered from land-based natural materials such as plants, animals, microbes, and minerals, etc. However, scientists have largely exploited terrestrial plants, animals, and microorganisms that have medicinal properties. Therefore, new resources for drug discovery must be explored. Oceans cover about $70 \%$ of the earth's surface area, but much of their biomedical potential has gone largely unexploited. Ecologists have estimated the number of species in the marine environment to be $0.5-10$ million, and most of these are yet to be discovered (108). Oceans, with some of the most diverse ecosystems on the planet, offer a rich source of naturally-occurring compounds that are potential drug candidates. In particular, marine organisms form a prominent component of the oceanic population, which significantly contribute in the production of cosmeceutical and pharmaceutical molecules with anti-bacterial, anti-cancer, anti-inflammatory and anti-oxidative activities, etc (109).

Over the past 30 years, marine organism-derived compounds with unique chemical structures and high levels of halogenation have been shown to produce beneficial effects in inflammation, cancer, infections, oxidative stress, and neurological disorders (110). Marine organisms such as coral, sponges and fish have a wide array of chemicals with various biological activities. For example, curacin A, which is obtained from a marine cyanobacterium Lyngbya majuscula found in Curaçao, shows potent antitumor activity (111). Chitooligosaccharide derivatives and phlorotannins have been identified in marine organisms as potential angiotensin-converting enzyme (ACE) inhibitors and they may also be developed as nutraceuticals and pharmaceuticals with potential anatihypertensive properties (112). In 2002, a group of researchers reported the discovery of a new strain of actinomycetes from ocean sediments - thus providing evidence for the first time for the widespread occurrence of indigenous actinomycete populations in marine sediments (113). In 2003, Fenical's group identified the structure of a new compound, salinosporamide A, from this new bacterial strain (114). Salinosporamide A is a novel proteasome inhibitor, which was found to be a potent growth inhibitor of tumors in preclinical studies (115). Other compounds derived from marine sources include didemnin, dolastatin-10, soblidotin, didemnin B, ecteinascidin 743, girolline, aplidine, cryptophycins (also arenastatin A), bryostatin 1, ILX 651, kahalalide F, E7389, discodermolide, ES-285 (spisulosine), HTI-286 (hemiasterlin derivative), squalamine, KRN-7000, vitilevuamide, laulimalide, curacin A, diazonamide, peloruside A, eleutherobin, sarcodictyin, thiocoraline, salicylihalimides A, ascididemnin, CGX - 1160, CGX 1007dictyodendrins, GTS - 21 (aka DMBX), manoalide, and IPL-576,092 (aka HMR-4011A), etc (116). These compounds have been shown to possess antitumor, analgesic, antiinflammatory, immunomodulatory, anti-allergic, and anti-viral activities.

To date, approximately 14,000 pharmacologically active compounds have been isolated from marine plants and animals (117). During the 3-year period from 2006-2009, a total of 812, 779 and 961 compounds, respectively, 
were isolated from marine microorganisms, phytoplankton, algae, sponges, coelenterates, bryozoans, molluscs, tunicates and echinoderms (118-120). Marine-derived compounds may be developed into new drugs that target various human diseases $(116,121,122)$. Marine bacteria and algae are therefore emerging as a promising source for drug discovery (123-125). In this connection, the State Ministry of Science and Technology in China has established specimen and gene banks of marine biotoic resources, which can be used for drug screening. From 1980 to 2005,811 compounds were isolated from invertebrates, including sponges, coelenterates, molluscs and echinoderms, all of which were caught in the South China Sea (126). About 16 drugs have been successfully developed from marine sources in China. In the USA, 15,000 compounds have been isolated from halobios annually, and more than 10 anti-cancer drugs developed from marine sources are currently undergoing preclinical or clinical studies. Japan and the European Union spend more than 100 million US dollar every year on marine biotics research. Oceans have thus become the largest resource for drug discovery (127-129).

\section{Human-derived compounds}

Knowledge of human biochemistry has grown tremendously during the last century, particularly during the last decade, because of the advent of molecular biology and modern biotechnology. Various human biomarkers have provided a solid foundation for understanding the metabolic processes which play a pivotal role in maintaining the growth and health of living systems as well as interactions among the environment, nutrition and genetics in relation to health. It is well established that there are 200 cell types and close to $50-100$ trillion cells, the basic unit of life, in an adult human. Every cell contains about 100,000 different proteins. The design and evolution of life involve a whole set of systems for protecting the individual against physical challenge, preventing the occurrence of diseases, and defending against the intrusion of pathogenic microorganisms. For example, the immune system recognizes proteins it encounters as foreign or hazardous, and then initiates measures to protect against a myriad of pathogens. It is therefore reasonable to suggest that human body should also offer a variety of biologically active molecular entities for drug discovery.

Up until now, many biogenic drugs have been found to exert beneficial effects on life-threatening diseases. Urine and urine extracts have been used for therapeutic purposes for centuries, and the first identified active componentis 3 - phenylacetylamino - 2, 6 piperidinedione (also called Antineoplaston A10)

(130) . Cell differentiation agent $2(\mathrm{CDA}-2)$ is a mixture of compounds isolated from healthy human urine in China. Previous reports have suggested that CDA-2 acts as a novel anti-cancer agent with multiple actions on cell proliferation, apoptosis, differentiation, and gene regulation in several solid tumors (131-133). Camel urine was used as a general tonic in traditional Arabic medicine. Modern studies have found that camel urine treatment produced significant cytotoxic effects in bone marrow cells in mice (134). Ursodeoxycholic acid, an endogenous bile acid used to treat cholestatic liver disease, was recently described as a modulator of $\mathrm{Mdm}$-2-mediated regulation of $\mathrm{p} 53$, a tumor suppressor protein (135).

In certain African countries where AIDS prevails, individuals amongst high-risk groups were found to be resistant to HIV infection. This observation has led to the speculation of the existence of anti-AIDS gene (136). Successful identification of such an anti-AIDS gene would offer a new hope in both the prevention and the curing of the disease through the production of vaccines and the development of novel drugs. Similarly, clues from genes protective against malaria might help in the design of new malaria therapies (137). The search for biological medicines should not, however, be limited to biological metabolites or newly-identified genes. Cellular components of the immune system, such as macrophages (or dendritic cells) and T-lymphocytes, offer an attractive alternative in which modified white blood cells might be used to defend against pathogens and eradicate cancer cells. In addition, system analysis of metabolic networks could help not only in identifying new drug targets, but also in developing a system-oriented drug design strategy (138).

The advent of personalized medicine will further bring about the development of pharmaceutics fitting the need of different individuals. At the present time, clinical biomarkers, such as gene-expression patterns and proteomic patterns, not only help to diagnose diseases, but also to create opportunities to match patients with therapies that are more likely to be effective and safe (139). It seems likely that pharmaceutical companies will eventually design the most efficacious and safe agent for patients with a defined set of biomarkers. In this regard, the practice of traditional Chinese medicine (TCM, or Zhong-Yi) always emphasizes the 
individualization of treatment. Therefore, the investigation of the "cause-and-effect" relationship between the presence of Chinese herbal ingredients and the change in clinical biomarkers will form the basis for the development of individualized medicine and/or pharmaceutics. The human body can be viewed as a combined pharmaceutical factory and general hospital whose operation is fully automated. It can defend itself against various pathogens and insults, but at the same it can undergo processes of self-healing in response to various ailments.

Modern drug design is mainly based on three strategic approaches: (1) disease mechanism-based molecular design; (2) effector-based molecular design; and (3) biomarker-based molecular design. So far, more than 480 validated drug targets have been identified, including receptors $(45 \%)$ and enzymes $(28 \%)$, in the human body (140). It is estimated that about 2200-3000 proteins can enhance the interactions between drug-like chemical compounds and targets in the human body $(141,142)$. Therefore, as biomarkers of life processes continue to be exploited, novel agents can be developed for therapeutic applications and health promotion.

\section{Food-derived compounds}

Foodstuffs are essential for maintaining life activities in humans; however, the roles of foods have been changed considerably, and they no longer are seen as simply the provider of energy (143). Ingredients such as carbohydrates, vitamins, minerals, amino acids, fatty acids, and other bioactive compounds in foodstuffs not only are capable of meeting caloric and general metabolic needs, but also affect metabolic functions that can influence cellular degeneration processes in the human body. The effect of food intake on health is dependent on one's eating habits with respect to food items. In general, organic crops contain higher levels of antioxidants and minerals, and lower levels of pesticide residues, nitrates and heavy metal contaminants, as compared to non-organic ones (144). Among different foodstuffs, vegetables are the major source of biologically active or useful substances such as vitamins, dietary fiber, antioxidants, and cholesterol-lowering compounds. Particularly, quercetin in the human diet is highly effective in reducing the DNA damage caused by antitumor agents (145). Generally, a greater health benefit is obtained from raw instead of cooked vegetables. Regular consumption of cruciferous vegetables/spices or polyphenol-rich foods is associated with a reduced incidence of cancer and a reduction of markers for neurodegenerative disorders (146,147). The identification, production and marketing of these food-derived bioactive ingredients could pave the way into a new era of drug discovery. The biologically active ingredients from foodstuffs can be extracted and concentrated or purified to enhance their efficacy and/or bioavailability.

To date, many potentially useful drugs or drug candidates have been found in foodstuffs. For example, isoflavones, which are abundantly present in soy bean and other plant sources, can not only ease menopausal symptoms, but reportedly reduce the incidence of heart disease and cancer, prevent prostate problems and improve bone health $(148,149)$. Genistein, an isoflavonoid present in soy products, has been shown to have anticancer effects, as evidenced by a link between a low occurrence of prostate cancer and a genistein-rich diet (150). Luteolin, a food-derived flavonoid, possesses a variety of pharmacological activities, including antioxidant, anti-inflammatory, antimicrobial and anticancer activities (151). Dietary sources of luteolin include carrots, peppers, celery, olive oil, peppermint, thyme, rosemary and oregano.

Palm oil and rice bran oil represent two major nutritional sources of natural tocotrienols, which are comprised of eight chemically distinct molecules (152). Tocotrienols, a subfamily of tocopherols, possesses powerful neuroprotective, anti-cancer, and cholesterol-lowering properties that are not often exhibited by tocopherols (153). Lycopene present in tomato was found to attenuate testicular injury caused by ischemia/reperfusion and adrenaline-induced myocardial infarction in rats $(154,155)$. Isothiocyanate and sulforaphane, two of the most widely investigated isothiocyanates, are representative electrophilic compounds from cruciferous vegetables that show promise as protectors against various diseases $(156,157)$. Bixin, a natural food coloring obtained from the seeds of the achiote tree (Bixa orellana), enhances insulin sensitivity in 3T3-L1 adipocytes through PPAR $\gamma$ activation and also reportedly kills cancer cells (158). Food-derived polyphenols and bioactive peptides have been suggested as anti-amyloid drugs for the treatment of Alzheimer's disease and they also may reduce the risk of cardiovascular diseases $(159,160)$. For instance, ACE-inhibitory peptides derived from foods have been shown to produce anti-hypertensive effects in clinical settings and anti-inflammatory effects in experimental conditions (161-163). Food-derived molecules/drugs might therefore exert beneficial 
effects in a wide range of diseases and might well play a significant role in the future as novel therapeutic agent.

\section{Bionic compounds from lower organisms}

The word bionic (encompassing biomimetics, bio-inspiration, biognosis, biomimicry, or bionical creativity engineering) was coined by Jack E. Steele in 1958. The transfer of technology between life forms and synthetic constructs is, according to proponents of bionic technology, desirable because evolutionary pressures typically force living organisms to become highly optimized and efficient. In medicine, bionics refers to the replacement or enhancement of organs or other body parts by mechanical components, which represents the development of engineering and technology based on natural biological systems. Recently, there has been a new wave of bio-inspired treatments that act through the reorganization of existing biological organs in an individual to enhance and/or regulate physiological and/or biochemical function(s) $(164,165)$. For example, bionic acids offer the benefits of alpha-hydroxyacids without irritation after cosmetic procedures. It also provides additional antioxidant/chelation, barrier strengthening, and moisturizing effects as well as anti-aging benefits (166).

Bionics in medicine not only means the replacement or enhancement of organs or other body parts by mechanical components, but also encompasses the development of new agents from lower-level living organisms or animals, i.e. "bionic pharmacy". For instance, antimicrobial peptides are an essential part of innate immunity that has evolved in most living organisms over 2.6 billion years to combat microbial challenges. These small peptides are multifunctional as effectors of innate immunity on skin and mucosal surfaces, representing a physical and chemical barrier against pathogen invasion, with a direct antimicrobial activity against various bacteria, viruses, fungi, and parasites, limiting pathogen growth in normal conditions. Moreover, they also possess additional roles in the regulation of adaptive immune responses, by recruiting or stimulating immune cells (167).

Both frogs and flies live in extremely dirty environments and a fly may carry 6 million bacteria. However, frogs and flies never die of infection. This suggests that certain antibiotic substance(s) may be present in these organisms. In this regard, a powerful antibiotic peptide was found on the skin of ranid frogs, which can destroy the bacterial wall without the development of resistance (168-171). This antibiotic peptide is still undergoing intensive preclinical studies. A variety of branched peptides, which are anti-microbial, anti-toxin and tumor-targeting agents, have been tested to identify single epitopes that can stimulate the immune system and might therefore prove useful for vaccine development (172). Also, seven anti-viral proteins were found in flies, which may be potential novel anti-viral agents $(173,174)$. In addition, apart from the production of bionic drugs from organisms in the environment, it should also be possible to simulate the functioning of human defense and immune systems and produce artificial white blood cells and lymphocytes as well as the related bioactive components to destroy pathogenic microorganisms (bacteria, viruses), and cancer cells. In theory, based on computer firewall technology concepts, we may weave a protective network for the human body to enhance or replace their own inherent defense system.

In addition, a potent analgesic compound called epibatidine was obtained from the skin extracts of the Ecuadorian poison frog (175). Teprotide, a peptide isolated from the venom of the Brazilian viper, was the lead compound for the development of the antihypertensive agents cilazapril and captopril, both of which are angiotensin-converting enzyme inhibitors (176). Toxins from lower organism such as snakes, spiders, scorpions, and insects often have very specific interactions with a macromolecular target in the body. They have been shown to be important tools for studying receptors, ion channels, and enzymes - and they can also provide lead compounds for the development of novel therapeutic agents.

\section{New uses for old drugs}

Once a drug has been approved for some use by some authoritative body such as the FDA in the USA, it can be prescribed for any use. Innovative new uses for old medicines are often developed, and a significant fraction of all prescriptions are used for multiple purposes (177). Major efforts currently being undertaken in drug discovery include the use of existing drugs for optimization, development of analogs, and treatment of other diseases. This approach in drug discovery has been successful. There are many examples and some of them are described below.

Botulinum toxin (with a lethal dose of 0.25 $\mu \mathrm{g}$ for an adult), which has been used in some parts of the world to treat muscle spasm, is now commonly used for the removal of facial wrinkles and to treat migraine headache (178-180). Statins, which are anti-hypercholesterolemic drugs, were 
found to produce an inhibitory effect on HIV $(181,182)$. Chloroquine, a drug for curing malaria, was also found to have an inhibitory effect on the SARS virus $(183,184)$. Quinolines have a significant antitumor effect on human breast cancer cells (185). Acetylsalicylic, which has been used for over a century as an analgesic, has for several years been used for its anti-platelet activity. Recently, it has been found that regular, long-term aspirin use reduces the risk of colorectal cancer in a dose-dependent manner $(186,187)$. Arsenic, first introduced for the treatment of syphilis, is now being used in the form of arsenic trioxide for treating promyelocytic leukemia (188). The antidepressant duloxetine, a serotonin and noradrenaline re-uptake blocker, can also be used for the management of detrusor instability (189). The diuretic ethacrynic acid might serve as the basis for the development of new anti-cancer drugs (190). Thalidomide, originally developed as a hypnotic in the 1950s and taken off the market because of its teratogenic effects, is now being used as an immunomodulator in a variety of diseases such as multiple myeloma and erythema nodosum leprosum (191,192). Minomycin belongs to a group of antibotics called tetracyclines and is used to treat various infections. It has been shown that minomycin can also produce neuroprotective effects in both experimental and clinical settings $(193,194)$. Some anticancer agents such as methotrexate and trimetrexate are active against malaria (195). Auranofin, a clinically established anti-arthritic metallo-drug, exhibits potent anti-malarial activity (196).

Although the technical advances in drug discovery have reached an unprecedented level, the success rate of finding a new and useful drug remains low. Therefore, the "new uses for old drugs", including marketed and off-marketed medicines, may represent a viable approach in drug discovery. In addition, we should pay close attention to the new uses of herbal drugs derived from CHM, Indian, Arabic/Islamic, and Western herbal remedies. New drug discovery should adopt a comprehensive approach and should not be limited to finding new chemical entity. Fig. 1 summarizes the major approaches in modern drug development.

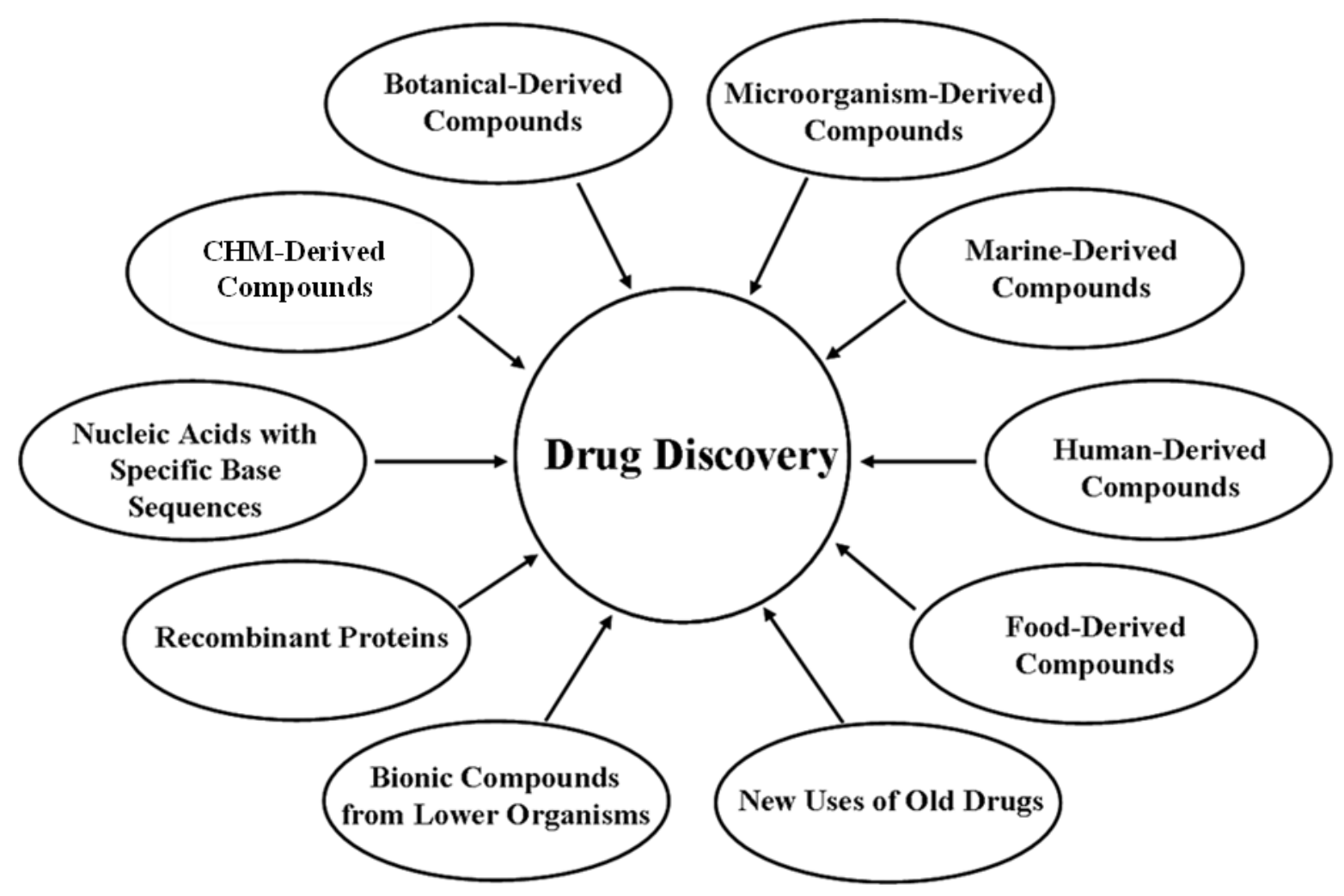

Figure 1. Contemporary approaches in drug discovery. 


\section{THREE KEY ISSUES OF PHARMA - CEUTICAL DRUG DEVELOPMENT}

It is a general understanding that new drug discovery is an increasingly difficult task. Here, we present three guiding principles that may be of utmost importance in enhancing the success rate of drug discovery (see Fig. 2).

\section{Application of new approaches/concepts}

Innovative drug discovery encompasses not only a technical component, but also new ideas or strategies. As we all know, the chemotherapy in modern medicine, i.e., killing pathogens (parasites, bacteria, and viruses, etc) and cancerous cells with chemicals, was developed from the know-how in bacterial staining. At that time people considered that chemicals which colored bacteria would also kill them. The impact of new technologies on drug $R \& D$ has been continually increasing over the past decades. Drug research has been refined by new technologies, and undoubtedly, technological advances can expedite the process of drug discovery in any era. Entering the $21^{\text {st }}$ century, the advent of biochemical techniques and cutting-edge technologies has made available a plethora of new approaches in drug design and invention. The utilization of biochemical assays (197), the employment of biomarkers (198), the exploitation of mathematical models $(199,200)$, microarray gene-expression technologies (201), the operation of molecular imaging (202), pharmaceutical crystal engineering (203), the application of high speed synthesis technologies (204), computational drug design (205) including computational methodologies firmly rooted in statistical thermodynamics (206), as well as the adoption of genotoxicity testing (207) have greatly facilitated the selection and optimization of lead compounds. Recognition of macromolecular targets for therapeutic intervention (208) and the causal relationship between ubiquitin and human diseases (209) has also added new facets in drug discovery. The application of artificial intelligence in the science of therapeutics may make personalized drug intervention possible in the near future (210). There is no doubt that the application of new technologies in the pharmaceutical industry has the potential to increase the success rate of development of new therapeutic entities, as well as changes in the concept of modern and traditional medicines.

Any scientific and technological development and their application originate from changes in the prevailing concept in a particular area of interest, and new drug R\&D is no exception. The introduction of new drugs into the marketplace involves not only the discovery and/or design of new compounds, but also the development of formulations and delivery systems for these therapeutic agents. One should make full use of modern technological means, even space technology, to promote drug development to meet human needs. While new chemical entities are synthesized, traditional remedies should be reformed using modern techniques with the adoption of new conceptual frameworks. In this regard, China has made remarkable achievements, which are described in more detail in our previous review (11).

The application of new technology often increases the cost of drug R\&D, resulting in drug prices that are beyond the reach of most people in developing countries. For example, biopharmaceuticals are among the most expensive medicines (they often cost more than 1000 US dollars per month), and their use has been increasing by $20 \%$ per year, accounting for more than 40 billion dollars of a 200 billion dollar pharmaceutical budget in the USA (211). In China, the price of a granulated form of CHM is twice that of the raw herb. As a result, poor people still tend to use raw herbs (212). The cost of drug R\&D should also be considered in decision-making in all phases of drug development in order to make new drugs affordable by all - including the poor (213).

\section{ADMET is conducted in the early stage of drug discovery}

An ideal drug should be efficacious, have high target affinity and specificity, as well as being soluble, stable and safe. In addition, it should also be inexpensive to manufacture, easy to formulate, and simple to deliver with the appropriate pharmacokinetic profile. In fact, many drugs in the market fail to deliver in one or more the above attributes because of their sub-optimal biophysical characteristics. Drug development, particularly for an ideal therapeutic agent, is a long, expensive and failure-prone process that requires multi-disciplinary collaboration within the pharmaceutical industry and among educational institutions, research laboratories, government regulators and health care professionals.

Despite a steady increase in the total amount of money spent on pharmaceutical R\&D over the past decades, the number of new drug approvals has declined in recent years. Typically, less than $10 \%$ of drug candidates that have progressed to the clinical trial stage will eventually become 
marketable drugs. The high rate of failure in drug development is in part due to an inadequate understanding of the pathological mechanism(s) underlying the disease to which the drug is targeted, as well as a lack of anticipation of the pharmacokinetic profile of absorption (A), distribution (D), metabolism (M), excretion (E) and toxicity (T), i.e. ADMET, of the drug during the early stage of research. For example, low solubility and poor permeability account for many pharmacokinetic failures and about thirty percent of drug molecules are rejected due to pharmacokinetic failures (214). Therefore implementation of this strategy can effectively save pharmaceutical companies significant amounts of development time and cost. To optimize the ADMET screening, an early prediction of human pharmacokinetics using physiologically based pharmacokinetic models is desirable (215).

One possible strategy for facilitating the process of drug $R \& D$ is to adopt the multi-parametric approach in which ADMET is determined at an early stage of drug research. Such an effort is likely to provide a useful support for lead optimization as well as clinical candidate selection. Drug-induced toxicity continues to account for more than $30 \%$ of compound attrition during the drug development process, and remains one of the major causes for drug withdrawal after approval (216,217). Drug candidates are now selected on the basis of acceptable metabolism/toxicology profiles in preclinical settings. To support this endeavor, new methodologies, which include a battery of in vitro assays based on animal or human hepatic cellular and sub-cellular drug-metabolizing systems, genetic and enzymatic toxicological tests, have been developed (218). Toxicity screening methods for early phase drug development include the 3-(4,5-dimethylthiazolyl-2)-2,5-diphenyltetrazoliu $\mathrm{m}$ bromide assay and the protein synthesis inhibition assay to determine cytotoxicity, the Ames test, the SOS chromotest and bone marrow micronuclei assay for genotoxicity test, as well as various cultured cells and animal models to test for reproductive and developmental toxicities, respectively (219).

\section{Respect for nature}

The high failure rate of drug development has revealed three additional problems during the process. Firstly, results obtained from experimental studies may not be directly applicable to clinical situations. Many drug candidates which have been shown to be efficacious and safe in preclinical studies failed to produce the expected clinical outcomes. Secondly, the molecular mechanism of a candidate drug may not reflect its biological action at the whole organism level. Moreover, the overall effect of a combination of drugs may not merely be a simple summation of individual actions. Thirdly, the primary objectives of experimental and clinical investigations of a drug candidate may not be the same. While experimental investigations are more or less targeted at publications in reputable journals, clinical studies primarily aim to find a new therapeutic intervention.

The current trend of drug discovery is guided by clues from nature in which CHM represents a major source. Mother Nature not only nourishes our life, but also provides us ammunition to fight against diseases. As such, the original purpose of creating human beings would not be defeated. Prior to the discovery of drugs for a certain diseases, natural forces may introduce a genetic change in humans, with the resultant phenotype being resistant to a lethal disease. The discovery of HIV resistance amongst high-risk groups, as mentioned earlier, may be a manifestation of such a natural force in sustaining human life. Ironically, while the evolving arsenal of naturally-occurring compounds and the immune defense system should prevent mankind from being wiped out by deadly pathogens, the chance of mankind's extinction by self-destructive forces, such as lethal weapons and environmental pollution, is getting higher. With the trust in Mother Nature, we should resort to natural sources in the search for new drugs to treat presently incurable diseases. Interestingly, the increased incidence of incurable diseases such as cancers and AIDS are paralleled by the evolution of new species of microorganisms. If the evolutional trend is applied to interpret this association, we have every reason to believe that drug discovery should follow a natural path.

Data have shown that $60 \%$ of the anti-cancer drugs and $75 \%$ of the anti-infective drugs approved from 1981 to 2002 were of natural origin, and $61 \%$ of all new chemical entities discovered in that period were inspired by natural products (220). Natural products account for 30\% of international drug sales, whereas more than $50 \%$ are synthetics manufactured by mimicking the active ingredients found in plants (221). More than $60 \%$ of the drugs that are on the market were derived from natural sources (222). Over 20 new drugs launched on the market between 2000 and 2005 originated from terrestrial plants, terrestrial microorganisms, marine organisms, or terrestrial vertebrates and invertebrates (223). About $50 \%$ of 
the drugs introduced to the market from 1984 to 2003 were derived directly or indirectly from small biogenic molecules in nature (224). These data indicate that nature and human body is the main way of drug discovery, therefore, we have no reason not to respect them.

\section{CONCLUSION}

The advent of molecular biology and, in particular, of genomic sciences is having a profound impact on drug discovery. Recombinant proteins and monoclonal antibodies have greatly enriched our therapeutic armamentarium, which have become the leading area of expansion in the biologic segment within the pharmaceutical industry. Genome sciences, combined with bioinformatics tools, allow us to dissect the genetic basis of multifactorial diseases and to determine the most suitable drug targets, thereby increasing the number of treatment options. The dramatic increase in the complexity of drug research is forcing changes in the institutional basis of this interdisciplinary endeavor. The biotechnology industry is establishing itself as the discovery arm of the pharmaceutical industry. In bridging the gap between academia and large pharmaceutical companies, biotechnology firms have been an effective instrument for technology transfer. Successful application and effective integration of relevant knowledge and technical know-how are essential for predicting outcomes and gauging risk in drug discovery. Nowadays, the translation of data from genomics and proteomics, as well as other high-throughput data mining technologies, into the understanding of complex systems underlying cell physiology is a key for successful drug design. Currently, drug-induced toxicity remains one of the major causes for the failure of new pharmaceuticals, and for the withdrawal of approved drugs from the market. Given the adverse side effects of most chemical drugs, scientists are endeavoring to introduce new drugs which are free of side effects. In the future, Mother Nature, including humans and various kinds of complementary and alternative medicines, are the main source for drug discovery.

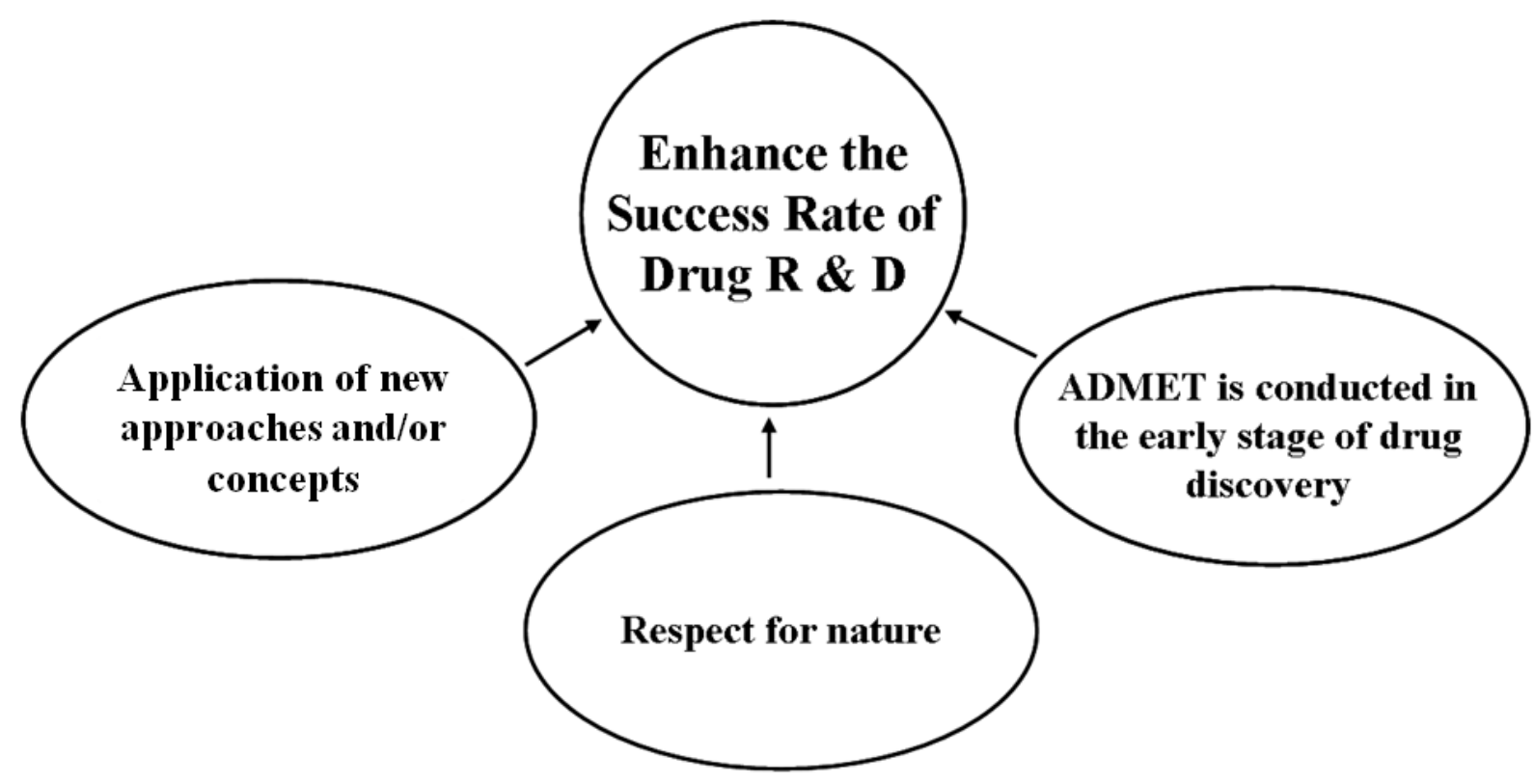

Figure 2. Key issues of drug discovery. 


\section{ACKNOWLEDGEMENTS}

This paper was supported by the National Natural Science Foundation of China (Grant No 31071989).

\section{REFERENCES}

1. Rishton GM. Natural products as a robust source of new drugs and drug leads: past successes and present day issues. Am J Cardiol, 101:43D-49D, 2008.

2. Reichert JM, Milne CP. Public and private sector contributions to the discovery and development of "impact" drugs. Am J Ther, 9:543-555, 2002.

3. Reichert JM. Trends in development and approval times for new therapeutics in the United States. Nat Rev Drug Discov, 2:695-702, 2003.

4. Munos B. Lessons from 60 years of pharmaceutical innovation. Nat Rev Drug Discov, 8:959-968, 2009.

5. Grabowski H. Are the economics of pharmaceutical research and development changing? Productivity, patents and political pressures. Pharmacoeconomics, 22(2 Suppl 2):15-24, 2004.

6. Vernon JA. Examining the link between price regulation and pharmaceutical R\&D investment. Health Econ, 14:1-16, 2005.

7. Tobinick EL. The value of drug repositioning in the current pharmaceutical market. Drug News Perspect, 22:119-125, 2009.

8. Reichert JM, Rochon SL, Zhang BD. Finding value in the U.S. Food and Drug Administration's Fast Track program. Drug News Perspect, 22:53-58, 2009.

9. Graul AI. Promoting, improving and accelerating the drug development and approval processes. Drug News Perspect, 21:36-43, 2008.

10. Graul AI, Revel L, Barrionuevo M, Cruces E, Rosa E, Verges C, Lupone B, Diaz N, Castaner R. The year's new drugs \& biologics - 2008. Drug News Perspect, 22:7-29, 2009.

11. Pan SY, Chen SB, Dong HG, Yu ZL, Dong JC, Long ZX, Fong WF, Han ong WF, Han YF, Ko KM. New Perspectives on Chinese Herbal Medicine (Zhong-Yao) Research and Development. Evid Based Complement Alternat Med, doi:10.1093/ecam/neq056, 2010.

12. Maruyama Y, Wakamatsu A, Kawamura Y, Kimura K, Yamamoto J, Nishikawa T, Kisu Y, Sugano S, Goshima N, Isogai T, Nomura N. Human Gene and Protein Database (HGPD): a novel database presenting a large quantity of experiment-based results in human proteomics. Nucleic Acids Res, 37:D762-766, 2009.

13. Bentley DR. The Human Genome Project - an overview. Med Res Rev, 20:189-196, 2000.

14. Heilker R, Wolff M, Tautermann CS, Bieler M. G-protein-coupled receptor-focused drug discovery using a target class platform approach. Drug Discov Today, 14:231-240, 2009.

15. Reynolds CH, Tounge BA, Bembenek SD. Ligand binding efficiency: trends, physical basis, and implications. J Med Chem, 51:2432-2438, 2008.

16. Manning MC, Chou DK, Murphy BM, Payne RW, Katayama DS. Stability of protein pharmaceuticals: an update. Pharm Res, 27:544-575, 2010.

17. Ellison D. Biopharmaceutical development and clinical manufacturing [updated 2008 Jun 9; cited 2010 Jan 25]. Available from: http://www.bionow.co.uk/uploads/documents/jun 08/bionow_1213884750_Dr_Derek_Ellison_Eden Biodesig.pdf.

18. Chemier JA, Fowler ZL, Koffas MA, Leonard E. Trends in microbial synthesis of natural products and biofuels. Adv Enzymol Relat Areas Mol Biol, 76:151-117, 2009.

19. Reichert JM. Monoclonal antibodies as innovative therapeutics. Curr Pharm Biotechnol, 9:423-430, 2008.

20. Robak T. Treatment of chronic lymphoid leukemias with monoclonal antibodies: current place and perspectives. Drug Dev Res, 69:373-387, 2008.

21. Debinski W. Molecular targeting with recombinant cytotoxins for the treatment of brain tumors. Drug Dev Res, 69:407-414, 2008.

22. Tabira T. Immunization therapy for Alzheimer disease: a comprehensive review of active immunization strategies. Tohoku J Exp Med, 220:95-106, 2010.

23. Hollander PA, Cefalu WT, Mitnick M, Lawrence D, Rosenstock J. Titration of inhaled human insulin (Exubera) in a treat-to-target regimen for patients with type 2 diabetes. Diabetes Technol Ther, 12:185-191, 2010.

24. Lau EM, Yozghatlian V, Kosky C, Moriarty C, Dentice R, Waugh R, Torzillo PJ, Bye PT. Recombinant activated factor VII for massive hemoptysis in patients with cystic fibrosis. Chest, 136:277-281, 2009.

25. Ramjoué $\mathrm{C}$. The transatlantic rift in genetically modified food policy. J Agr Environ Ethic, 20:419-436, 2007.

26. Kumar GB, Ganapathi TR, Revathi CJ, Srinivas L, Bapat VA. Expression of hepatitis B surface antigen in transgenic banana plants. Planta, 222:484-493, 2005.

27. Zhou H, Liu ZG, Sun ZW, Huang Y, Yu WY, Generation of stable cell lines by site-specific integration of transgenes into engineered Chinese hamster ovary strains using an FLP-FRT system. J Biotechnol, 147:122-129, 2010. 
28. Jelkmann W. Erythropoiesis stimulating agents and techniques: a challenge for doping analysts. Curr Med Chem, 16:1236-1247, 2009.

29. Gibson DG, Glass JI, Lartigue C, Noskov VN, Chuang RY, Algire MA, Benders GA, Montague MG, Ma L, Moodie MM, Merryman C, Vashee S, Krishnakumar R, Assad-Garcia N, Andrews-Pfannkoch C, Denisova EA, Young L, Qi ZQ, Segall-Shapiro TH, Calvey CH, Parmar PP, Hutchison CA 3rd, Smith HO, Venter JC. Creation of a bacterial cell controlled by a chemically synthesized genome. Science, 329:52-56, 2010.

30. Tanaka T, Kuroki M, Hamada H, Kato K, Kinugasa T, Shibaguchi H, Zhao J, Kuroki M. Cancer-targeting gene therapy using tropism-modified adenovirus. Anticancer Res, 27:3679-3684, 2007.

31. Shirakawa T. Clinical trial design for adenoviral gene therapy products. Drug News Perspect, 22:140-145, 2009.

32. Blaese RM. Development of gene therapy for immunodeficiency: adenosine deaminase deficiency. Pediatr Res, 33(Suppl 1):S49-53, 1993.

33. Wasserfall $\mathrm{CH}$, Herzog RW. Gene therapy approaches to induce tolerance in autoimmunity by reshaping the immune system. Curr Opin Investig Drugs, 10:1143-1150, 2009.

34. Romano G, Marino IR, Pentimalli F, Adamo V, Giordano A. Insertional mutagenesis and development of malignancies induced by integrating gene delivery systems: implications for the design of safer gene-based interventions in patients. Drug News Perspect, 22:185-196, 2009.

35. Schilsky RL. Personalized medicine in oncology: the future is now. Nat Rev Drug Discov, 9:363-366, 2010.

36. Borden EC, Raghavan D. Personalizing medicine for cancer: the next decade. Nat Rev Drug Discov, 9:343-344, 2010.

37. Pérez CM. Can ginkgo biloba combat diseases? $\mathrm{P}$ R Health Sci J, 28:66-74, 2009.

38. Leistner E, Drewke C. Ginkgo biloba and ginkgotoxin. J Nat Prod, 73:86-92, 2010.

39. Miller K, Neilan B, Sze DM. Development of Taxol and other endophyte produced anti-cancer agents. Recent Pat Anticancer Drug Discov, 3:14-19, 2008

40. Cui L, Su XZ. Discovery, mechanisms of action and combination therapy of artemisinin. Expert Rev Anti Infect Ther, 7:999-1013, 2009.

41. Hounsome N, Hounsome B, Tomos D, Edwards-Jones G. Plant metabolites and nutritional quality of vegetables. J Food Sci, 73:R48-65, 2008.

42. Aggarwal BB. Signalling pathways of the TNF superfamily: a double-edged sword. Nat Rev
Immunol, 3:745-756, 2003.

43. Chan, SH, Lee HM, Yang F, Che CM, Wong CCL, Abagyan R, Leung CH, Ma DL. Structure-Based Discovery of Natural Product-Like TNF- $\alpha$ Inhibitors. Angew Chem Int Ed Engl, 49:2860-2863, 2010.

44. Pavlović RD, Lakusić B, Doslov-Kokorus Z, Kovacević N. Arbutin content and antioxidant activity of some ericaceae species. Pharmazie, 64:656-659, 2009.

45. Mothana RA, Gruenert R, Bednarski PJ, Lindequist $U$. Evaluation of the in vitro anticancer, antimicrobial and antioxidant activities of some Yemeni plants used in folk medicine. Pharmazie, 64:260-268, 2009.

46. Bansal T, Jaggi M, Khar RK, Talegaonkar S. Emerging significance of flavonoids as P-glycoprotein inhibitors in cancer chemotherapy. J Pharm Pharm Sci, 12:46-78, 2009.

47. Bernhaus A, Ozsvar-Kozma M, Saiko P, Jaschke M, Lackner A, Grusch M, Horvath Z, Madlener S, Krupitza G, Handler N, Erker T, Jaeger W, Fritzer-Szekeres M, Szekeres T. Antitumor effects of KITC, a new resveratrol derivative, in AsPC-1 and BxPC-3 human pancreatic carcinoma cells. Invest New Drugs, 27:393-401, 2009.

48. Sun AY, Wang Q, Simonyi A, Sun GY. Resveratrol as a therapeutic agent for neurodegenerative diseases. Mol Neurobiol, 41:375-383, 2010.

49. Tunali-Akbay T, Sehirli O, Ercan F, Sener G. Resveratrol protects against methotrexate-induced hepatic injury in rats. J Pharm Pharm Sci, 13:303-310, 2010.

50. Gong S, Hao J, Xia Y, Liu X, Li J. Inhibitory effect of bionic fungicide 2-allylphenol on Botrytis cinerea (Pers. ex Fr.) in vitro. Pest Manag Sci, 65:1337-1343, 2009.

51. Hurwitz JL, Zhan X, Brown SA, Bonsignori M, Stambas J, Lockey TD, Sealy R, Surman S, Freiden P, Jones B, Martin L, Blanchard J, Slobod KS. HIV-1 vaccine development: tackling virus diversity with a multi-envelope cocktail. Front Biosci, 13:609-620, 2008.

52. Erdine S. Compliance with the treatment of hypertension: the potential of combination therapy. J Clin Hypertens (Greenwich), 12:40-46, 2010.

53. Mahadevan S, Park Y. Multifaceted therapeutic benefits of Ginkgo biloba L. chemistry, efficacy, safety, and uses. J Food Sci, 73:R14-19, 2008.

54. Li WF, Jiang JG, Chen J. Chinese medicine and its modernization demands. Arch Med Res, 39:246-251, 2008.

55. Deng ZL. Application of new techniques in the innovative research of Chinese herbal medicine. Chin Pharm, 16:58-59, 2007 (in Chinese).

56. Au WY, Kwong YL. Arsenic trioxide: safety issues and their management. Acta Pharmacol Sin, 
29:296-304, 2008.

57. Rust DM, Soignet SL. Risk/benefit profile of arsenic trioxide. Oncologist, Suppl 2:29-32, 2001.

58. Dart RC. Medical toxicology. Williams \& Wilkins, Philadelphia, pp1393-1401, 2004.

59. Liu J, Lu Y, Wu Q, Goyer RA, Waalkes MP. Mineral arsenicals in traditional medicines: Orpiment, realgar, and arsenolite. J Pharmacol Exp Ther, 326:363-368, 2008.

60. Hua HG, Wang JH, Q-in SD. Ancient and modern application of pi-Shuang. Chin J Chin Mater Med, 28:186-188, 2003 (in Chinese).

61. Thomas X, Troncy J. Arsenic: a beneficial therapeutic poison - a historical overview. Adler Mus Bull, 35:3-13, 2009.

62. Xu SN, Chen JP, Liu JP, Xia Y. Efficacy of arsenic trioxide for acute promyelocytic leukemia: a systematic review and meta-analysis. J Chin Integr Med, 7:801-808, 2009 (in Chinese).

63. Leu L, Mohassel L. Arsenic trioxide as first-line treatment for acute promyelocytic leukemia. Am J Health Syst Pharm, 66:1913-1918, 2009.

64. Douer D, Tallman MS. Arsenic trioxide: New clinical experience with an old medication in hematologic malignancies. J Clin Oncol, 23:2396-2410, 2005.

65. Röllig C, Illmer T. The efficacy of arsenic trioxide for the treatment of relapsed and refractory multiple myeloma: a systematic review. Cancer Treat Rev, 35:425-430, 2009.

66. Berenson JR, Yeh HS. Arsenic compounds in the treatment of multiple myeloma: a new role for a historical remedy. Clin Lymphoma Myeloma, 7:192-198, 2006.

67. Li LH, Li HM. Progression of foundational and clinical studies on use of arsenic trioxide in treatment of lymphoma-review. J Exp Hematol, 15:1335-1339, 2007 (in Chinese).

68. Li H, Xiong MM. Review of arsenic trioxide effect on human hepatocarcinoma. Cancer Res Clin, 18:712-714, 2006 (in Chinese).

69. Dilda PJ, Hogg PJ. Arsenical-based cancer drugs. Cancer Treat Rev, 33:542-564, 2007.

70. Wang R, Yan H, Tang XC. Progress in studies of huperzine $\mathrm{A}$, a natural cholinesterase inhibitor from Chinese herbal medicine. Acta Pharmacol Sin, 27:1-26, 2006.

71. Zhang HY, Zheng CY, Yan H, Wang ZF, Tang LL, Gao X, Tang XC. Potential therapeutic targets of huperzine A for Alzheimer's disease and vascular dementia. Chem Biol Interact, 175:396-402, 2008.

72. Guo B, Xu L, Wei Y, Liu C. Research advances of huperzia serrata (Thunb.) Trev. Chin J Chin Mater Med, 34:2018-2023, 2009 (in Chinese).

73. Desilets AR, Gickas JJ, Dunican KC. Role of huperzine a in the treatment of Alzheimer's disease. Ann Pharmacother, 43:514-518, 2009.
74. Zhang JC, Xing JH, Song YH, Wang ZM, Zhang HY. Recent advances in studies on herb biological of huperzia serrata(Thunb.)Trev. Chin Wild Plant Resources, 27:1-5, 2008 (in Chinese).

75. Fu Y, Li S, Zu Y, Yang G, Yang Z, Luo M, Jiang S, Wink M, Efferth T. Medicinal chemistry of paclitaxel and its analogues. Curr Med Chem, 16:3966-3985, 2009.

76. Li B, Zhu WL, Chen KX. Advances in the study of berberine and its derivatives. Acta Pharm Sin, 43:773-787, 2008 (in Chinese).

77. Carmargo LM, de Oliveira S, Basano S, Garcia $\mathrm{CR}$. Antimalarials and the fight against malaria in Brazil. Ther Clin Risk Manag, 5:311-317, 2009.

78. Liu GT. Bicyclol: a novel drug for treating chronic viral hepatitis B and C. Med Chem, 5:29-43, 2009.

79. Liu GT. From the study of Fructus schizandrae to the discovery of biphenyl dimethyl-dicarboxylate. Acta pharm Sin, 18:714-720, 1983 (in Chinese).

80. Tang Y, Hu W, Li Y, Zhang CZ. Synthesis of metabolites of bicyclol. Acta pharm Sin, 42:1054-1057, 2007 (in Chinese).

81. Chang JB, Wang Q, Li YF. Synthesis and biological activity of Wuweizisu $\mathrm{C}$ and analogs. Curr Top Med Chem, 9:1660-1675, 2009.

82. Pan SY, Yang R, Dong H, Yu ZL, Ko KM. Bifendate treatment attenuates hepatic steatosis in cholesterol/bile salt- and high-fat diet-induced hypercholesterolemia in mice. Eur J Pharmacol, 552:170-175, 2006.

83. Pan SY, Dong H, Yu ZL, Zhao XY, Xiang CJ, Wang H, Fong WF, Ko KM. Bicyclol, a synthetic dibenzocyclooctadiene derivative, decreases hepatic lipids but increases serum triglyceride level in normal and hypercholesterolaemic mice. J Pharm Pharmacol, 59:1657-1662, 2007.

84. Pan SY, Yu ZL, Dong H, Xiang CJ, Fong WF, Ko KM. Ethanol Extract of Fructus Schisandrae Decreases Hepatic Triglyceride Level in Mice Fed with a High Fat/Cholesterol Diet, with Attention to Acute Toxicity. Evid Based Complement Alternat Med, doi:10.1093/ecam/nep070, 2009.

85. Pan SY, Dong H, Zhao XY, Xiang CJ, Fang HY, Fong WF, Yu ZL, Ko KM. Schisandrin B from Schisandra chinensis reduces hepatic lipid contents in hypercholesterolaemic mice. J Pharm Pharmacol, 60:399-403, 2008.

86. Hanai H, Sugimoto K. Curcumin has bright prospects for the treatment of inflammatory bowel disease. Curr Pharm Des, 15:2087-2094, 2009.

87. Bar-Sela G, Epelbaum R, Schaffer M. Curcumin as an anti-cancer agent: review of the gap between basic and clinical applications. Curr Med Chem, 17:190-197, 2010.

88. Sikora E, Bielak-Zmijewska A, Mosieniak G, Piwocka K. The promise of slow down ageing may come from curcumin. Curr Pharm Des, 
16:884-892, 2010.

89. Fischbach MA, Walsh CT. Antibiotics for emerging pathogens. Science, 325:1089-1093, 2009.

90. Petrosillo N, Capone A, Di Bella S, Taglietti F. Management of antibiotic resistance in the intensive care unit setting. Expert Rev Anti Infect Ther, 8:289-302, 2010.

91. Newman DJ, Cragg GM. Microbial antitumor drugs: natural products of microbial origin as anticancer agents. Curr Opin Investig Drugs, 10:1280-1296, 2009.

92. Weng TC, Yang YH, Lin SJ, Tai SH. A systematic review and meta-analysis on the therapeutic equivalence of statins. J Clin Pharm Ther, 35:139-151, 2010.

93. Corbetta G, Ponticelli C. Once-a-day administration of everolimus, cyclosporine, and steroid after renal transplantation: a review of the rationale. Transplant Proc, 42:1303-1307, 2010.

94. Aguilar JC, Rodríguez EG. Vaccine adjuvants revisited. Vaccine, 25:3752-3762, 2007.

95. Williams NT. Probiotics. Am J Health Syst Pharm, 67:449-458, 2010.

96. Liong MT, Shah N P. Effects of a Lactobacillus casei synbiotic on serum lipoprotein, intestinal microflora, and organic acids in rats. J Dairy Sci, 89:1390-1399, 2006.

97. Linsalata M, Cavallini A, Messa C, Orlando A, Refolo MG, Russo F. Lactobacillus rhamnosus GG influences polyamine metabolism in HGC-27 gastric cancer cell line: a strategy toward nutritional approach to chemoprevention of gastric cance. Curr Pharm Des, 16:847- 853, 2010.

98. Galdeano CM, de Moreno de Le Blanc A, Vinderola G, Bonet MEB, Perdigon G. Proposed model: mechanisms of immunomodulation induced by probiotic bacteria. Clin Vaccine Immunol, 14:485-492, 2007.

99. Russell WR, Scobbie L, Chesson A, Richardson AJ, Stewart CS, Duncan SH, Drew JE, Duthie GG. Anti-inflammatory implications of the microbial transformation of dietary phenolic compounds. Nutr Cancer, 60:636-642, 2008.

100.Tlaskalová-Hogenová H, Stepánková R, Hudcovic T, Tucková L, Cukrowska B, Lodinová-Zádníková R, Kozáková H, Rossmann P, Bártová J, Sokol D, Funda DP, Borovská D, Reháková Z, Sinkora J, Hofman J, Drastich P, Kokesová A. Commensal bacteria (normal microflora), mucosal immunity and chronic inflammatory and autoimmune diseases. Immunol Lett, 93:97-108, 2004.

101.Kinross J.M, von Roon AC, Holmes E, Darzi A, Nicholson JK. The human gut microbiome: implications for future health care. Curr Gastroenterol Rep, 10:396-403, 2008.

102.Possemiers S, Grootaert C, Vermeiren J, Gross G,
Marzorati M, Verstraete W, Van de Wiele T. The intestinal environment in health and disease recent insights on the potential of intestinal bacteria to influence human health. Curr Pharm Des, 15:2051-2065, 2009.

103.Ley RE. Obesity and the human microbiome. Curr Opin Gastroenterol, 26:5-11, 2010.

104.Othman M, Agüero R, Lin HC. Alterations in intestinal microbial flora and human disease. Curr Opin Gastroenterol, 24:11-16, 2008.

105.O'Hara AM, Shanahan F. The gut flora as a forgotten organ. EMBO Rep, 7:688-693, 2006.

106. Chhibber S, Kaur S, Kumari S. Therapeutic potential of bacteriophage in treating Klebsiella pneumoniae B5055-mediated lobar pneumonia in mice. J Med Microbiol, 57:1508-1513, 2008.

107.Williams R. Review article: bacterial flora and pathogenesis in hepatic encephalopathy. Aliment Pharmacol Ther, 25 (Suppl 1):17-22, 2007.

108. Cooper EL. Drug discovery, CAM and natural products. Evid Based Complement Altern Med, 1:215-217, 2004.

109.Pallela R, Na-Young Y, Kim SK. Anti-photoaging and photoprotective compounds derived from marine organisms. Mar Drugs, 8:1189-1202, 2010.

110.Villa FA, Gerwick L. Marine natural product drug discovery: Leads for treatment of inflammation, cancer, infections, and neurological disorders. Immunopharmacol Immunotoxicol, 32:228-237, 2010.

111. Chang Z, Sitachitta N, Rossi JV, Roberts MA, Flatt PM, Jia J, Sherman DH, Gerwick WH. Biosynthetic pathway and gene cluster analysis of curacin A, an antitubulin natural product from the tropical marine cyanobacterium Lyngbya majuscula. J Nat Prod, 67:1356-1367, 2004.

112.Wijesekara I, Kim SK. Angiotensin-I-converting enzyme (ACE) inhibitors from marine resources: prospects in the pharmaceutical industry. Mar Drugs, 8:1080-1093, 2010.

113. Mincer TJ, Jensen PR, Kauffman CA, Fenical W. Widespread and persistent populations of a major new marine actinomycete taxon in ocean sediments. Appl Environ Microbiol, 68:5005-5011, 2002.

114.Fenical W, Jensen PR, Palladino MA, Lam KS, Lloyd GK, Potts BC. Discovery and development of the anticancer agent salinosporamide A (NPI-0052). Bioorg Med Chem, 17:2175-2180, 2009.

115. Chauhan D, Hideshima T, Anderson KC. A novel proteasome inhibitor NPI-0052 as an anticancer therapy. Br J Cancer, 95:961-965, 2006.

116.Singh R, Sharma M, Joshi P, Rawat DS. Clinical status of anti-cancer agents derived from marine sources. Anticancer Agents Med Chem, 8:603-617, 2008. 
117.Adrian TE. Novel marine-derived anti-cancer agents. Curr Pharm Des, 13:3417-3426, 2007.

118. Blunt JW, Copp BR, Hu WP, Munro MH, Northcote PT, Prinsep MR. Marine natural products. Nat Prod Rep, 24:31-86, 2007.

119.Blunt JW, Copp BR, Hu WP, Munro MH, Northcote PT, Prinsep MR. Marine natural products. Nat Prod Rep, 25:35-94, 2008.

120.Blunt JW, Copp BR, Hu WP, Munro MH, Northcote PT, Prinsep MR. Marine natural products. Nat Prod Rep, 26:170-244, 2009.

121. Schwartsmann G, Da Rocha AB, Mattei J, Lopes R. Marine-derived anticancer agents in clinical trials. Expert Opin Investig Drugs, 12:1367-1383, 2003.

122. Haefner B. Drugs from the deep: marine natural products as drug candidates. Drug Discov Today, 8:536-544, 2003.

123. Williams PG. Panning for chemical gold: marine bacteria as a source of new therapeutics. Trends Biotechnol, 27:45-52, 2009.

124. Freile-Pelegrin Y, Robledo D, Chan-Bacab MJ, Ortega-Morales BO. Antileishmanial properties of tropical marine algae extracts. Fitoterapia, 79:374-377, 2008.

125. Martinez A. Marine-derived drugs in neurology. Curr Opin Investig Drugs, 8:525-530, 2007.

126.Zhang W, Guo YW, Gu Y. Secondary metabolites from the South China Sea invertebrates: chemistry and biological activity. Curr Med Chem, 13:2041-2090, 2006.

127.Zhang W, Xue S, Zhao Q, Zhang X, Li J, Jin M, Yu X, Yuan Q. Biopotentials of marine sponges from China oceans: past and future. Biomol Eng, 20:413-419, 2003.

128. Fenical W. New pharmaceuticals from marine organisms. Trends Biotechnol, 15:339-341, 1997.

129. Molinski TF, Dalisay DS, Lievens SL, Saludes JP. Drug development from marine natural products. Nat Rev Drug Discov, 8:69-85, 2009.

130.Burzynski SR. Antineoplastons: history of the research (I). Drugs Exp Clin Res, 12(suppl 1):1-9, 1986.

131.Lin WC, Wu YW, Lai TY, Liau MC. Effect of CDA-II, urinary preparation, on lipofuscin, lipid peroxidation and antioxidant systems in young and middle-aged rat brain. Am J Chin Med, 29:91-99, 2001.

132.Huang J, Yang M, Liu H, Jin J. Human urine extract CDA-2 induces apoptosis of myelodysplastic syndrome-derived MUTZ-1 cells through the PI3K/Akt signaling pathway in a caspase-3-dependent manner. Acta Pharmacol Sin, 29:951-964, 2008.

133. Huang J, Yang M, Liu H, Jin J. CDA-II, a urinary preparation, induces growth arrest and apoptosis of human leukemia cells through inactivation of nuclear factor-kappaB in a caspase-dependent manner. Food Chem Toxicol, 47:40-49, 2009.

134.al-Harbi MM, Qureshi S, Ahmed MM, Raza M, Baig MZ, Shah AH. Effect of camel urine on the cytological and biochemical changes induced by cyclophosphamide in mice. $\mathrm{J}$ thnopharmacol, 52:129-137, 1996.

135. Amaral JD, Xavier JM, Steer CJ, Rodrigues CM. The role of $\mathrm{p} 53$ in apoptosis. Discov Med, 9:145-152, 2010.

136. Fowke KR, Nagelkerke NJ, Kimani J, Simonsen JN, Anzala AO, Bwayo JJ, MacDonald KS, Ngugi EN, Plummer FA. Resistance to HIV-1 infection among persistently seronegative prostitutes in Nairobi, Kenya. Lancet, 348:1347-1351, 1996.

137. Gurwitz D. Malaria drugs: clues from malaria resistance genetics. Drug Dev Res, 71:1-3, 2010.

138. Ma H, Goryanin I. Human metabolic network reconstruction and its impact on drug discovery and development. Drug Discov Today, 13:402-408, 2008.

139. Trusheim MR, Berndt ER, Douglas FL. Stratified medicine: strategic and economic implications of combining drugs and clinical biomarkers. Nat Rev Drug Discov, 6:287-293, 2007.

140.Drews J, Ryser S. The role of innovation in drug development. Nat Biotechnol, 15:1318-1319, 1997.

141.Russ AP, Lampel S. The druggable genome: an update. Drug Discov Today, 10:1607-1610, 2005.

142.Dunkel M, Günther S, Ahmed J, Wittig B, Preissner R. SuperPred: drug classification and target prediction. Nucleic Acids Res, 36:W55-59, 2008.

143. MacDonald L, Foster BC, Akhtar H. Food and therapeutic product interactions - a therapeutic perspective. J Pharm Pharm Sci, 12:367-377, 2009.

144.Györéné KG, Varga A, Lugasi A. A comparison of chemical composition and nutritional value of organically and conventionally grown plant derived foods. Orv Hetil, 147:2081-2090, 2006 (in Hungarian).

145. Celik H, Arinç E. Evaluation of the protective effects of quercetin, rutin, naringenin, resveratrol and trolox against idarubicin-induced DNA damage. J Pharm Pharm Sci, 13:231-241, 2010.

146. Calabrese V, Cornelius C, Trovato A, Cavallaro M, Mancuso C, Di Rienzo L, Condorelli D, De Lorenzo A, Calabrese EJ. The hormetic role of dietary antioxidants in free radical-related diseases. Curr Pharm Des, 6:877-883, 2010.

147. Bastianetto S, Krantic S, Quirion R. Polyphenols as potential inhibitors of amyloid aggregation and toxicity: possible significance to Alzheimer's disease. Mini Rev Med Chem, 8:429-435, 2008.

148.Song WO, Chun OK, Hwang I, Shin HS, Kim BG, Kim KS, Lee SY, Shin D, Lee SG. Soy isoflavones 
as safe functional ingredients. $\mathrm{J}$ Med Food, 10:571-580, 2007.

149. Moţa M, Gârgavu S, Popa S, Schiopu S, Panduru NM, Moţa E. Soya-the medicine food product. Rom J Intern Med, 45:113-121, 2007.

150.Molinié B, Georgel P. Genetic and epigenetic regulations of prostate cancer by genistein. Drug News Perspect, 22:247-254, 2009.

151.López-Lázaro M. Distribution and biological activities of the flavonoid luteolin. Mini Rev Med Chem, 9:31-59, 2009.

152. Sen CK, Khanna S, Roy S. Tocotrienols in health and disease: the other half of the natural vitamin $\mathrm{E}$ family. Mol Aspects Med, 28:692-728, 2007.

153.Sen CK, Khanna S, Rink C, Roy S. Tocotrienols: the emerging face of natural vitamin E. Vitam Horm, 76:203-261, 2007.

154.Hekimoglu A, Kurcer Z, Aral F, Baba F, Sahna E, Atessahin A. Lycopene, an antioxidant carotenoid, attenuates testicular injury caused by ischemia/reperfusion in rats. Tohoku J Exp Med, 218:141-147, 2009.

155.Parvin R, Akhter N. Protective effect of tomato against adrenaline-induced myocardial infarction in rats. Bangladesh Med Res Counc Bull, 34:104-108, 2008.

156. Cheung KL, Kong AN. Molecular targets of dietary phenethyl isothiocyanate and sulforaphane for cancer chemoprevention. AAPS J, 12:87-97, 2010.

157. Nakamura Y, Miyoshi N. Electrophiles in foods: the current status of isothiocyanates and their chemical biology. Biosci Biotechnol Biochem, 74:242-255, 2010.

158. Takahashi N, Goto T, Taimatsu A, Egawa K, Katoh S, Kusudo T, Sakamoto T, Ohyane C, Lee JY, Kim YI, Uemura T, Hirai S, Kawada T. Bixin regulates mRNA expression involved in adipogenesis and enhances insulin sensitivity in 3T3-L1 adipocytes through PPARgamma activation. Biochem Biophys Res Commun, 390:1372-1376, 2009.

159. Bastianetto S, Krantic S, Quirion R. Polyphenols as potential inhibitors of amyloid aggregation and toxicity: possible significance to Alzheimer's disease. Mini Rev Med Chem, 8:429-435, 2008.

160.Erdmann K, Cheung BW, Schröder H. The possible roles of food-derived bioactive peptides in reducing the risk of cardiovascular disease. $\mathrm{J}$ Nutr Biochem, 19:643-654, 2008.

161. Aihara K, Ishii H, Yoshida M. Casein-derived tripeptide, Val-Pro-Pro (VPP), modulates monocyte adhesion to vascular endothelium. J Atheroscler Thromb, 16:594-603, 2009.

162. Aluko RE. Technology for the production and utilization of food protein-derived anti-hypertensive peptides: a review. Recent Pat
Biotechnol, 1:260-267, 2007.

163.Guang C, Phillips RD. Plant food-derived Angiotensin I converting enzyme inhibitory peptides. J Agric Food Chem, 57:5113-5120, 2009.

164.Ashrafian H, Darzi A, Athanasiou T. Autobionics: a new paradigm in regenerative medicine and surgery. Regen Med, 5:279-288, 2010.

165.Green DW. Tissue bionics: examples in biomimetic tissue engineering. Biomed Mater, doi: 10.1088/1748-6041/3/3/034010, 2008.

166.Green BA, Yu RJ, Van Scott EJ. Clinical and cosmeceutical uses of hydroxyacids. Clin Dermatol, 27:495-501, 2009.

167.Hervé JC. Therapeutic potential of peptide motifs - part III. Curr Pharm Des, 16:1021-1023, 2010.

168.Conlon JM. Reflections on a systematic nomenclature for antimicrobial peptides from the skins of frogs of the family Ranidae. Peptides, 29:1815-1819, 2008.

169.Conlon JM, Kolodziejek J, Nowotny N. Antmicrobial peptides from ranid frogs: taxonomic and phylogenetic markers and a potential source of new therapeutic agents. Biochim Biophys Acta, 1696:1-14, 2004.

170.Barra D, Simmaco M. Amphibian skin: a promising resource for antimicrobial peptides. Trends Biotechnol, 13:205-209, 1995.

171.Gordon YJ, Romanowski EG, McDermott AM. A review of antimicrobial peptides and their therapeutic potential as anti-infective drugs. Curr Eye Res, 30:505-515, 2005.

172.Pini A, Falciani C, Bracci L. Branched peptides as therapeutics. Curr Protein Pept Sci, 9:468-477, 2008.

173. Takeuchi O, Akira S. RIG-I-like antiviral protein in flies. Nat Immunol, 9:1327-1328, 2008.

174. Deddouche S, Matt N, Budd A, Mueller S, Kemp C, Galiana-Arnoux D, Dostert C, Antoniewski C, Hoffmann JA, Imler JL. The DExD/H-box helicase Dicer-2 mediates the induction of antiviral activity in drosophila. Nat Immunol, 9:1425-1432, 2008.

175.Carroll FI. Epibatidine structure-activity relationships. Bioorg Med Chem Lett, 14:1889-1896, 2004.

176.Nemec K, Schubert-Zsilavecz M. From teprotide to captopril. Rational design of ACE inhibitors. Pharm Unserer Zeit, 32:11-16, 2003 (in German).

177. Tabarrok A. From off-label prescribing towards a new FDA. Med Hypotheses, 72:11-13, 2009.

178. Chang SP, Tsai HH, Chen WY, Lee WR, Chen PL, Tsai TH. The wrinkles soothing effect on the middle and lower face by intradermal injection of botulinum toxin type A. Int J Dermatol, 47:1287-1294, 2008.

179.Aguggia M. Treating headaches with botulinum 
toxin. Neurol Sci, 29 (Suppl 1):S137-139, 2008.

180. Millán-Guerrero RO, Isais-Millán S, Barreto-Vizcaíno S, Rivera-Castaño L, Rios-Madariaga C. Subcutaneous histamine versus botulinum toxin type A in migraine prophylaxis: a randomized, double-blind study. Eur J Neurol, 16:88-94, 2009.

181. Amet T, Nonaka M, Dewan MZ, Saitoh Y, Qi X, Ichinose S, Yamamoto $\mathrm{N}$, Yamaoka $\mathrm{S}$. Statin-induced inhibition of HIV-1 release from latently infected U1 cells reveals a critical role for protein prenylation in HIV-1 replication. Microbes Infect, 10:471-480, 2008.

182.Gilbert C, Bergeron M, Méthot S, Giguère JF, Tremblay MJ. Statins could be used to control replication of some viruses, including HIV-1. Viral Immunol, 18:474-489, 2005.

183. Keyaerts E, Vijgen L, Maes P, Neyts J, Van Ranst M. In vitro inhibition of severe acute respiratory syndrome coronavirus by chloroquine. Biochem Biophys Res Commun, 323:264-268, 2004.

184. Vincent MJ, Bergeron E, Benjannet S, Erickson BR, Rollin PE, Ksiazek TG, Seidah NG, Nichol ST. Chloroquine is a potent inhibitor of SARS coronavirus infection and spread. Virol J, doi:10.1186/1743-422X-2-69, 2005.

185.Gakhar G, Ohira T, Shi A, Hua DH, Nguyen TA. Antitumor effect of substituted quinolines in breast cancer cells. Drug Dev Res, 69:526-534, 2008.

186. Chan AT, Ogino S, Fuchs CS. Aspirin and the risk of colorectal cancer in relation to the expression of COX-2. N Engl J Med, 356:2131-2142, 2007.

187. Chan AT, Giovannucci EL, Meyerhardt JA, Schernhammer ES, Wu K, Fuchs CS. Aspirin dose and duration of use and risk of colorectal cancer in men. Gastroenterology, 134:21-28, 2008.

188.Jurcic JG, Soignet SL, Maslak AP. Diagnosis and treatment of acute promyelocytic leukemia. Curr Oncol Rep, 9:337-344, 2007.

189. Basu M, Duckett JR. Detrusor overactivity successfully treated with duloxetine. J Obstet Gynaecol, 27:438-440, 2007.

190. Wang R, Li C, Song D, Zhao G, Zhao L, Jing Y. Ethacrynic acid butyl-ester induces apoptosis in leukemia cells through a hydrogen peroxide mediated pathway independent of glutathione S-transferase P1-1 inhibition. Cancer Res, 67:7856-7864, 2007.

191.Durk HA. Maintenance therapy for multiple myeloma with particular emphasis on thalidomide. Onkologie, 29:582-590, 2006.

192. Villahermosa LG, Fajardo TT Jr, Abalos RM, Balagon MV, Tan EV, Cellona RV, Palmer JP, Wittes J, Thomas SD, Kook KA, Walsh GP, Walsh DS. A randomized, double-blind, double-dummy, controlled dose comparison of thalidomide for treatment of erythema nodosum leprosum. Am J Trop Med Hyg, 72:518-526, 2005.

193. Orsucci D, Calsolaro V, Mancuso M, Siciliano G. Neuroprotective effects of tetracyclines: molecular targets, animal models and human disease. CNS Neurol Disord Drug Targets, 8:222-231, 2009.

194.Noble W, Garwood CJ, Hanger DP. Minocycline as a potential therapeutic agent in neurodegenerative disorders characterised by protein misfolding. Prion, 3:78-83, 2009.

195.Nzila A, Okombo J, Becker RP, Chilengi R, Lang $\mathrm{T}$, Niehues T. Anticancer agents against malaria: time to revisit? Trends Parasitol, 26:125-129, 2010.

196. Sannella AR, Casini A, Gabbiani C, Messori L, Bilia AR, Vincieri FF, Majori G, Severini C. New uses for old drugs. Auranofin, a clinically established antiarthritic metallodrug, exhibits potent antimalarial effects in vitro: Mechanistic and pharmacological implications. FEBS Lett, 582:844-847, 2008.

197. Rishton GM. Failure and success in modern drug discovery: guiding principles in the establishment of high probability of success drug discovery organizations. Med Chem, 1:519-527, 2005.

198. Kuhlmann J. The applications of biomarkers in early clinical drug development to improve decision-making processes. Ernst Schering Res Found Workshop, 59:29-45, 2007.

199. Westerhoff HV, Mosekilde E, Noe CR, Clemensen AM. Integrating systems approaches into pharmaceutical sciences. Eur J Pharm Sci, 35:1-4, 2008.

200.Rescigno A. The two faces of pharmacokinetics. J Pharm Pharm Sci, 13:38-42, 2010.

201.Goodsaid FM, Amur S, Aubrecht J, Burczynski ME, Carl K, Catalano J, Charlab R, Close S, Cornu-Artis C, Essioux L, Fornace AJ Jr, Hinman L, Hong H, Hunt I, Jacobson-Kram D, Jawaid A, Laurie D, Lesko L, Li HH, Lindpaintner K, Mayne J, Morrow P, Papaluca-Amati M, Robison TW, Roth J, Schuppe-Koistinen I, Shi L, Spleiss O, Tong W, Truter SL, Vonderscher J, Westelinck A, Zhang L, Zineh I. Voluntary exploratory data submissions to the US FDA and the EMA: experience and impact. Nat Rev Drug Discov, 9:435-445, 2010.

202.Janiszewski JS, Liston TE, Cole MJ. Perspectives on bioanalytical mass spectrometry and automation in drug discovery. Curr Drug Metab, 9:986-994, 2008.

203.Peterson ML, Hickey MB, Zaworotko MJ, Almarsson O. Expanding the scope of crystal form evaluation in pharmaceutical science. J Pharm Pharm Sci, 9:317-326, 2006.

204.Niu G, Chen X. Has molecular and cellular imaging enhanced drug discovery and drug 
development? Drugs R D, 9:351-368, 2008.

205.Clark M, Meshkat S, Talbot G, Konteatis Z, Ludington J, Zou J, Freedman SJ, Wiseman JS. Developing technologies in biodefense research: computational drug design. Drug Dev Res, 70:279-287, 2009.

206. Michel J, Essex JW. Prediction of protein-ligand binding affinity by free energy simulations: assumptions, pitfalls and expectations. J Comput Aided Mol Des, May 28 10.1007/s10822-010-9363-3, 2010.

207. Custer LL, Sweder KS. The role of genetic toxicology in drug discovery and optimization. Curr Drug Metab, 9:978-985, 2008.

208.Eglen RM, Reisine T. Photoproteins: important new tools in drug discovery. Assay Drug Dev Technol, 6:659-671, 2008.

209.Petroski MD. The ubiquitin system, disease, and drug discovery. BMC Biochem, 9(Suppl 1):S7, 2008.

210.Ehrman TM, Barlow DJ, Hylands PJ. Phytochemical informatics and virtual screening of herbs used in Chinese medicine. Curr Pharm Des, 16:1785-1798, 2010.

211. Gillick MR. Controlling off-label medication use. Ann Intern Med. 2009; 150:344-347.

212. Shi J, Yang JW, Kuang JX. Thoughts on the Chinese herbal medicine granulaes. Acta Acad Med Zunyi, 32:557-586, 2003 (in Chinese).

213.Paul SM, Mytelka DS, Dunwiddie CT, Persinger CC, Munos BH, Lindborg SR, Schacht AL. How to improve R\&D productivity: the pharmaceutical industry's grand challenge. Nat Rev Drug Discov, 9:203-214, 2010.

214.Jain D, Pathak D, Pathak K. Pharmaceutical product development technologies based on the biopharmaceutical classification system. Pharmazie, 64:483-490, 2009.
215.Jones HM, Gardner IB, Watson KJ. Modelling and PBPK simulation in drug discovery. AAPS J, 11:155-166, 2009.

216.Prakash C, Sharma R, Gleave M, Nedderman A. In vitro screening techniques for reactive metabolites for minimizing bioactivation potential in drug discovery. Curr Drug Metab, 9:952-964, 2008.

217.Ryan TP, Stevens JL, Thomas CE. Strategic applications of toxicogenomics in early drug discovery. Curr Opin Pharmacol, 8:654-660, 2008.

218. Watson P. Live cell imaging for target and drug discovery. Drug News Perspect, 22:69-79, 2009.

219.Greene N, Naven R. Early toxicity screening strategies. Curr Opin Drug Discov Devel, 12:90-97, 2009.

220.Newman DJ, Cragg GM, Snader KM. Natural products as sources of new drugs over the period 1981-2002. J Nat Prod, 66:1022-1037, 2003.

221.Grabley S, Thiericke R. Bioactive agents from natural sources: trends in discovery and application. Adv Biochem Eng Biotechnol, 64:101-154, 1999.

222.Molinari G. Natural products in drug discovery: present status and perspectives. Adv Exp Med Biol, 655:13-27, 2009.

223. Chin YW, Balunas MJ, Chai HB, Kinghorn AD. Drug discovery from natural sources. AAPS J, 8:E239-253, 2006.

224. Vuorelaa P, Leinonenb M, Saikkuc P, Tammelaa P, Rauhad JP, Wennberge T, Vuorela H. Natural products in the process of finding new drug candidates. Curr Med Chem, 11:1375-1389, 2004. 